\title{
THE EFFECT OF PATRONAGE POLITICS \\ ON CITY GOVERNMENT IN \\ AMERICAN CITIES, 1900-1910
}

\author{
Rebecca Menes
}

Working Paper 6975

http://www.nber.org/papers/w6975

\author{
NATIONAL BUREAU OF ECONOMIC RESEARCH \\ 1050 Massachusetts Avenue \\ Cambridge, MA 02138 \\ February 1999
}

The author gratefully acknowledges fellowship support from the National Science Foundation, the Sloan Foundation, the Josephine de Karman Foundation, the Richard D. Irwin Foundation, and the Joint HarvardMIT Research Training Group in Positive Political Economy. The author wishes to thank Claudia Goldin, Edward Glaeser, Aaron Tornell, David Cutler, Lance Davis, Michael Edelstein, Lawrence Katz, Michael Kremer, Naomi Lamoreaux, Jean-Laurent Rosenthal, Ken Sokoloff and Jeffrey G. Williamson for advice and assistance, Robert Whaples for data in machine readable format, the participants in the Harvard Economic History Workshop, the Harvard Economic History Graduate Tea, the Joint Harvard-MIT Research Training Group in Positive Political Economy, colleagues in the U.C.L.A. Department of Political Science, and the 35th Annual Cliometrics Conference in Lawrence, Kansas, for many helpful suggestions. All errors remain the responsibility of the author. Any views expressed in this paper are those of the author only and not those of the National Bureau of Economic Research.

(C) 1999 by Rebecca Menes. All rights reserved. Short sections of text, not to exceed two paragraphs, may be quoted without explicit permission provided that full credit, including ${ }^{\circledR}$ notice, is given to the source. 
The Effect of Patronage Politics on City

Government in American Cities, 1900-1910

Rebecca Menes

NBER Working Paper No. 6975

February 1999

JEL No. N41, R53

ABSTRACT

In this paper I explore the effect of patronage or "machine" politics on government performance in American cities during the Progressive era. I use game theoretic models and an empirical analysis of spending and public goods provision during the first decade of the twentieth century in a cross section of American cities with and without governments dominated by political machines. The ability to buy votes relaxes the electoral constraints on the government. Taxes, budgets, municipal wages, and (unobserved) corruption are all predicted to rise under a patronage based regime. But in a city, patronage politics does not relax the incentives to provide public goods. A politician who buys his way into office will still be motivated to provide optimal levels of government goods and services because he can capture the resulting locational rents in higher taxes and graft. Empirically, city governments dominated by political machines paid city government employees more and had larger budgets but provided high levels of public goods.

\section{Rebecca Menes}

Department of Political Science

University of California - Los Angeles

4298 Bunche Hall, Box 95-1472

Los Angeles, CA 90095-1472

and NBER

menes@ucla.edu 
INTRODUCTION

Government corruption is common in many new democracies in the developing and post-Soviet worlds and is not unknown in older, established democracies, including the United States. Government corruption is blamed for slowing economic growth and exacerbating inequality by inflating taxes and extralegal exactions, distorting private markets, and preventing governments from providing public goods efficiently and in sufficient quantity. ${ }^{1}$ Corruption in democracies is often embedded in patronage based political institutions - large, hierarchical political parties, organized in many cases along ethnic or clan lines, in which political support is bought with material rewards such as access to government jobs and services. Today such political institutions exist in polities as diverse as the national governments of India, Japan, Mexico, and Italy and the city governments of Istanbul and Moscow, and are still active in subnational U.S. governments, including the "outer boroughs" of New York City: Queens, Brooklyn and the Bronx (Newfield and Barrett 1988). A patronage based political party, in American parlance a "political machine," is apparently able to insulate corrupt elected officials from voter ire by buying votes - granting favors to and making individual deals with a winning coalition of voters. Understanding the structure and impact of government corruption in democracies depends on understanding the political machine.

American city government at the turn of the twentieth century provides an unparalleled opportunity to study how the ability to buy votes relaxes the constraints that voters otherwise impose on their government. At the beginning of the twentieth century, city governments in many, but not all, cities in the U.S. were dominated by large, well-organized, and well-documented, political machines. In this paper I

${ }^{1}$ Corruption is understood here to mean the misuse of the powers of government by elected and appointed government employees for material gain. For a general introduction to the literature on corruption, see the anthology edited by Heidenheimer, et al. (1989). For a theoretical discussion of the impact of corruption on growth, see Murphy, Shleifer and Vishny (1993); for an empirical cross country comparison of the impact of corruption, see Mauro (1995). 
investigate how the ability to buy votes relaxes, or fails to relax, the constraints on politicians to keep taxes and expenses down and to provide public goods. ${ }^{2}$

There were about 100 cities with populations greater than 50,000 in 1910. These cities were small, open economies in the U.S. national economy, competing with each other and subject to similar (although not identical) legal, cultural, and economic constraints. Unlike modern U.S. cities, the Progressive era municipalities were fiscally independent, raising their own revenues from local taxes and bonds and determining their own budgets. The performance of local governments mattered. In 1902 local governments generated $55 \%$ of all government revenue and spent $59 \%$ of all government outlays, compared to $22 \%$ and $25 \%$ today (Wallis 1993). The roads, sewers, schools, transportation, electricity, gas and water provided by local governments or by government franchisees were vital to the health, wealth, and happiness of residents. Between 1903 and 1931 data on city government performance, fiscal and real, were collected by the U.S. Bureau of the Census. Although no one collected an official list of political machines, I am able to develop a subjective measure of the presence of a political machine based on the rich historical literature on Progressive era cities. Using my coding of cities and the Census information I compare government performance in machine dominated and non-machine dominated cities, including the per capita government budget, overall and by department, the wages of government employees, and the provision of one the most important and costly types of public infrastructure, the proportion of roads paved with durable stone, brick, and asphalt paving. The proportion of durable paving on city roads provides a measure of something notoriously difficult to measure — the government's success in producing real public goods.

\footnotetext{
${ }^{2}$ In other work I have addressed the internal structure of the machine, the causes of machine politics, and the distortions that machine politics introduces into the private economy (Menes 1994, 1997).
} 
The historical literature does not provide a satisfactory theoretical model of the relationship between machine politics and government performance. Instead I develop a game theoretic model of vote buying and government behavior in a small open economy democracy. The model is influenced by rational choice models of government such as Mançur Olson's stationary bandit, Shleifer and Vishny's kleptocratic bureaucrats, and median voter and Tiebout models of democracy in local government (Olson 1991; Shleifer and Vishny 1993; Tiebout 1956).

In the historical literature the study of machine governments as providers of public goods has been overshadowed by the study of those aspects of government that appeared unique to the machine system, such as patronage, the development of personal political networks, the demands of poor voters for material rewards, and the costs of maintaining the internal hierarchy of the machine (Forthal 1946; Merton 1957; Reid and Kurth 1992; Wilson 1961, among others). There are a few scholars who have addressed the relationship between political machines and the performance of the more traditional responsibilities of local government. In a field as intensively investigated as Progressive era urban politics most important questions have at least been asked. The debate on the link between machine politics and public goods, however, is still relatively undeveloped. The leading hypothesis is historical rather than theoretical and it has not been carefully tested. Samuel Hays, in his influential 1964 article on the "Politics of Reform" argued that machine dominated governments must have been poor providers of public goods because the opponents of the political machines had higher demands for public goods than did machine supporters. Large quantities of qualitative evidence support the conclusion that political reform was popular among middle and upper-middle class voters, whereas patronage-based machines were supported by lower and 
lower-middle class voters. ${ }^{3}$ Although less well established, it is likely that machine opponents ("reformers") and machine supporters did differ in the relative importance they attached to public goods and to private favors. The rich probably did want public goods such as parks, roads, and museums, while the poor valued individual favors, such as a bushel of coal or a job (Merton 1957). From the presumed pattern of demand Hays argued that machine dominated city governments must have spent much of the city budget on private favors and minimized spending on public goods and services, especially on the public infrastructure demanded disproportionately by the middle-class and the rich, while reform-dominated governments must have reduced spending on favors and built more infrastructure.

Hays' thesis may be true, or false (my empirical analysis suggests that Hays' thesis fails), but whether true or false the theory is not a model of patronage politics and policy outcomes. The relationship between favors and public goods which Hays proposes is not different from standard theories of voting, where the demands of different voters determine outcomes. Hays' thesis can be considered as a null hypothesis - patronage and vote buying did not matter, only the demands of the voters in the winning coalition — against which to test a theory of patronage.

Between 1890 and 1920 cities were providing increasing quantities of new or improved public goods, including water systems, sewer systems, bridges, and paving (Cain and Rotella 1990; Rauch 1995). Jon Teaford's study of national trends in both political organization and government performance, the charmingly titled Unheralded Triumph, does much to advance the argument that American cities, both machine dominated and non-machine, adapted to rapid growth and technological change with enviable speed and flexibility (Teaford 1984). American city governments often provided new public goods more

\footnotetext{
${ }^{3}$ See Hays (1964), Hofstadter (1962), and Rice (1977) on the nature of reformers, Gosnell ([1937] 1968), Merton (1957), Rice (1977), Reid and Kurth (1992), and Scott (1969) on the role of machines in the lives of poorer voters.
} 
quickly and in greater quantity than municipal governments in England and Germany, both countries whose professional, civil service dominated city governments were viewed by American political reformers as models of urban reform. Teaford does not explicitly compare machine and non-machine cities, but according to his analysis many of the larger cities were dominated by political machines and were among the first to introduce the new public goods. Teaford does address the relationship between patronage and performance within particular city administrations, showing that patronage-dependent politicians in many cities employed patronage techniques to staff the city council, administration, courts, and police, where the value of political loyalty was high and the technical demands on employees were low, but adopted merit driven policies and careful attention to professional preparation in departments such as water, fire, and highways, where new technologies demanded new technical skills. Teaford's findings are neither a model nor a theory; they describe empirical regularities that suggest Hays' analysis may not be complete.

In this paper I analyze the effect of patronage politics on the costs and performance of municipal government. The paper has four sections: a model, a discussion of the historical data against which the model is tested, an empirical analysis of government wages, budgets, and public goods provision, and a conclusion. Patronage politics does change government behavior. According to the model vote buying relaxes some of the constraints on a government. A kleptocratic administration uses private vote-buying to purchase the acquiescence of a majority of voters and then to extract rents from a (presumably protesting) minority. The presence and the fiscal effect of machine politics is found empirically, as well. I observe a higher government wage premium, presumably a reflection of vote buying through patronage jobs, and higher budgets, presumably a reflection of the fiscal burden of patronage and corruption, in the machinedominated cities. According to the model, however, and unlike Hays' prediction, the ability to buy votes does not relax the motivation to provide public goods. The ability of voters to leave the city, not the ability of 
voters to vote, is what determines the level of the government's provision of public goods in a city. I test the provision of public goods using the provision of durable paving on city streets. Durable paving, as opposed to dirt or gravel paving, was a valuable, expensive, and relatively uncommon, public good in 1910. I find the machine dominated cities provide as much, or more, durable paving as non-machine dominated cities.

\section{MACHINE POLITICS: MODEL AND IMPLICATIONS}

Patronage, or machine, politics is the politics of private transactions between voters and politicians. Votes are "bought" in exchange for government provided favors. A non-machine politician is unable to make private deals and depends solely on policy-based appeals, such as tax rates and the provision of public goods, to win elections. (The machine politician does not eschew policy based appeals; he combines a public policy platform with private favors.)

In this section I model how vote buying relaxes the constraints on an elected government. I start with a median voter model. The provision of public goods is the policy issue of concern to voters. I add the option of buying votes with private payoffs, loosening the constraint on the winning politician to provide the median voter's preferred policy. I borrow the kleptocrat from Mancur Olson's stationary bandit model of government: machine politicians want to maximize the profits from political control, or the total tax revenue less the costs of providing public goods (Olson 1991). Finally, because I am predicting the performance of city, not national, governments, I introduce elements of a Tiebout model: city residents leave if they can do better elsewhere, taking taxes, wages, and access to the public good into account. However I first solve the model in the non-Tiebout setting, where voters cannot leave, to show which results are driven by vote buying, and which by voter mobility. The closed border model can be interpreted as a machine government in a country, able to close borders, or in a city with extremely low wages outside the city. If economic 
opportunities are sufficiently limited outside the city then city residents will respond to high taxes not by leaving, but by changing the economic choices they make within the city. The last description may capture the economic choice facing city residents in a developing country, where the rural wage is extremely low and there is a large, untaxed and unregulated "informal" economy within the city.

\subsection{The models}

Model 1: voters cannot leave the city

Consider a single city with $\mathrm{N}$ residents, each with one vote. There are two employment opportunities in the city: a high wage market sector and a low wage domestic sector. Only workers in the market sector are taxed. All city residents enjoy access to a city provided public good, G. The public good is produced by a constant returns to scale technology and therefore $\mathrm{G}$ can also be expressed in terms of the numeraire output. The utility function of a city resident has the form:

$$
U_{i}=w-t+p_{i}+u_{i}(G)
$$

where $\mathrm{w}=$ wage;

$\mathrm{t}=$ per capita tax if the worker is in the market sector, 0 otherwise;

$p_{i}=$ the private favor a voter receives from the machine government;

$u_{i}(G)=$ the utility derived from public goods, du/dG $>0, d^{2} u_{i} / d^{2}<0$.

The first order conditions for $\mathrm{G}^{*}$, the socially optimal quantity of public good, are:

$$
\text { Marginal Cost of } \mathrm{G}^{*}=Q_{N} d u_{i} / \mathrm{dG}^{*}
$$

such that the tax rate needed to pay for $\mathrm{G}^{*}$ is not so high that workers drop out of the taxable sector:

$$
\mathrm{t}^{*} \leq \mathrm{w}^{\text {market }}-\mathrm{w}^{\text {domestic }} .
$$

All voters derive identical utility from the public good, $G ; u_{i}(G)=u(G)$ for all i. By construction the marginal 
cost of $\mathrm{G}$ is 1 , and by symmetry du/dG is the same for all city residents, therefore: ${ }^{4}$

$$
\mathrm{du} / \mathrm{dG} \mathrm{G}^{*}=1 / \mathrm{N}
$$

and

$$
t^{*}=G / N
$$

provided $\mathrm{G} / \mathrm{N} \leq \mathrm{w}^{\text {market }}-$ w $^{\text {domestic }}$, a constraint which need not bind.

The city is run by a single elected official, the mayor. There are two kinds of politicians who can run for mayor, machine and non-machine. Non-machine politicians control two policy instruments: a tax, t, which is the same for all inhabitants of the city, and the quantity of public goods, G. Machine politicians control t and $G$ and are also able to offer each voter a private transfer $p_{i}$, the price of a vote. In theory the $p_{i}$ can be either positive or negative, although in this model with identical voters the $p_{i}$ are always positive or zero.

To make it as difficult as possible for the machine candidate to win, I assume the non-machine candidate credibly offers the policy $\left(t^{\star}, G^{*}\right)$ that optimizes social welfare. The assumption captures the intuition that there is free entry into politics by non-machine candidates and therefore the winning candidate will offer the median voter's preferred level of public goods. ${ }^{5}$ The machine candidate, on the other hand, will offer the combination $\left(t^{\text {machine }}, G^{\text {machine }},\left\{p_{i}\right\}\right.$ ) that maximizes the revenue extracted from the city. Therefore the machine has as its objective function:

$$
\operatorname{Max}_{G, t, p} t \cdot N-G-\sum_{N} p_{i}
$$

The first constraint on the machine is that $(.5 \mathrm{~N}+1)$ of the voters, the machine supporters, must be at least

\footnotetext{
${ }^{4}$ In this specification all voters are identical. The model may be extended by allowing wages or demand for $\mathrm{G}$ to vary across voters. Such an extension does not alter the implications of this model, but does produce interesting hypotheses concerning the conditions which favor the development of machines (Menes 1997).

${ }^{5}$ Changing the political alternative changes the vote price, $p_{i}$, but does not the amount of public good produced by a machine politician in either the closed (model 1) or open (model 2) city. The kleptocratic patronage politician provides public goods to lower the cost of buying the election and to increase the sustainable tax rate, not to match competing politicians. Changing the quality of the political opposition will change the vote price, $p_{\mathrm{i}}$, in both models.
} 
as happy with the machine as they would be with the candidate offering the socially optimal package of taxes and public goods: ${ }^{6}$

$$
w-t+p+u(G) \geq U^{*}
$$

The second constraint on the machine is that the workers must stay in the taxable market sector. Too high a tax rate causes the workers to shift to the untaxable domestic sector. Thus the machine tax rate must satisfy the constraint:

$$
t^{\text {machine }} \leq \mathrm{W}^{\text {market }}-\mathrm{w}^{\text {domestic }} \text {. }
$$

The above constraint will bind for a kleptocrat. Comparing eq. (6) with eq. (3b) reveals that, as expected, the kleptocratic machine imposes a higher tax on residents than is socially optimal.

Solving eq. (6) for $t$ and substituting into eq. (5), solving eq. (5) for the $p_{i}$ (treating all $p_{i}$ greater than zero as equal by symmetry and dropping the subscript), and substituting for $p$ in the machine objective function, eq. (4), reduces the machine objective function to:

$$
\operatorname{Max}_{G}(.5 N+1) \cdot u(G)-G \text {. }
$$

The first order condition for the maximization is:

$$
\mathrm{du} / \mathrm{dG}^{\text {machine }}=1 /(.5 \mathrm{~N}+1) .
$$

Comparing eq. (8) with eq. (2) shows that du/d $G^{\text {machine }}$ is larger than $d u / d G^{*}$ for any value of $\mathrm{N}$ greater than 2, which means, since $d^{2} u / d G^{2}<0$, that $G^{\text {machine }}<G^{*}$. The winning machine candidate offers less than the socially optimal quantity of public goods at a higher than socially optimal tax rate.

\footnotetext{
${ }^{6}$ This formulation assumes that ballots are secret. By 1900 most cities had adopted the secret, or Australian ballot. While machine politicians could at times circumvent the secret ballot for certain voters, stuffing ballot boxes and following voters into the voting booth also absorbed machine resources. The ability to observe votes will lower the price paid for a vote because each voter knows his vote is unlikely to be the marginal vote. A voter will be willing to sell his vote for less than the true value of his preference for the optimal candidate over the machine candidate if the machine can observe the vote; if the machine cannot observe the vote the voter will take the payment, and then vote his own best interest. In model 1 the ability to observe voters in the voting booth would lower the provision of public goods, but it would not in model 2 .
} 
Model 2: voters can leave the city

Everything remains as in the first case except that the untaxed sector is moved out of the city into a rural hinterland; $w^{\text {domesic }}$ is now called $w^{\text {rural }}$. Neither taxes nor public goods are found in the rural hinterland. ${ }^{?}$ Changing the economy changes the winning machine platform to $G^{\text {machine }}=G^{*}$; the machine politician now provides the optimal quantity of public goods. Taxes are still higher than the voters would prefer. Intuitively, the city government uses access to the public good, G, to keep voters in the city (and hence in the taxable sector.) The revenue extracted by the city government is maximized when the utility of living in the city is maximized. The kleptocrat therefore solves the same problem as a social welfare maximizing politician. Of course taxes are higher in the machine city than they would be with a social welfare maximizing government; the machine politician taxes away the extra utility that voters gain from higher city wages and city public goods, returning only enough in private favors to "buy" the election.

Formally, the machine objective function remains eq. (4). The first constraint, on the voters who sell their votes, remains eq. (5). The second constraint, on the voters who are exploited by the machine, is the constraint that changes:

$$
w-t+u(G) \geq w^{\text {rural }} .
$$

Solving eq. (5) for the wage rate $w$ and substituting into eq. (9) produces the solution for the price of a vote:

$$
p=U^{*}-w^{\text {rural }} \text {. }
$$

Solving eq. (9) for $t$ and substituting the solutions for $p$ and $t$, the objective function reduces to:

$$
\operatorname{Max}_{G} N \cdot u(G)-G+\left\{N \cdot w-N \cdot w^{\text {rural }}-(.5 N+1) \cdot\left(U^{*}-w^{\text {rural }}\right)\right\} .
$$

Because everything in braces, $\{\cdot\}$, is a constant, the first order condition for maximizing the machine's objective function is:

\footnotetext{
${ }^{7}$ The presence of cities in the hinterland does not alter the fundamental conclusions of this model as long as each city resident is located in the city where he receives the highest utility. If two cities are perfect substitutes for their residents then a machine candidate cannot extract any revenue from the city, cannot pay for votes, and does not win the election.
} 


$$
\mathrm{du} / \mathrm{dG}=1 / \mathrm{N}
$$

The solution for $G$ is the quantity $G^{*}$ which optimizes social welfare, the same solution as that of the ideal candidate. The machine government produces the socially optimal quantity of public goods, $\mathrm{G}^{\star}$. Overall voter utility is lower than optimal because the machine still imposes a higher tax rate than is optimal.

\subsection{Comparative Statics and Implications of the models}

The construction of the models naturally suggests comparing the outcomes for politicians and for voters in the two types of cities, closed and open borders, holding constant the wage in the untaxed sector ( $w^{\text {domestic }}$ in the city with closed borders, model 1 , equal to $w^{\text {rural }}$ in the city with open borders, model 2). The comparison between a closed and an open city is somewhat misleading, however. If $w^{\text {domestic }}$ in a closed city is equal to $w^{\text {rural }}$ in an open city then the voters do better in the closed city and the politicians do better in the open city, but it would be incorrect to assume that politicians in a particular city would ever choose to open a closed border. A more illuminating comparative static is to consider combining the two models in a single city so that all three options are available to a city resident: work in the taxed market sector at a wage $w^{\text {market }}$, work in the untaxed domestic sector within the city at a wage $w^{\text {domestic }}$, and work outside the city in the untaxed rural sector at a wage $w^{\text {rural }}$. When all three options are available, if $w^{\text {rural }}=w^{\text {domestic }}$, then model 1, the closed border city, is the applicable model. Since utility in the rural sector is equal simply to the wage, $\mathrm{w}^{\text {rural }}$, but utility in the domestic sector is equal to the wage plus the utility derived from access to whatever public goods are available in the city, $w^{\text {domestic }}+u\left(G^{\text {machine }}\right)$, when taxed too high a city resident would rather enter the domestic sector than leave the city.

If we carry out the thought experiment of holding conditions in the city constant and raising the rural wage it is relatively straightforward to discover that migration in response to high taxes does not become an attractive alternative for city residents until $w^{\text {rural }}=w^{\text {domestic }}+u\left(G^{\text {machine }}\right)$, where $d u / d G^{\text {machine }}=$ 
$1 /(.5 N+1)$. For rural wages found in the interval $w^{\text {domestic }}+u\left(G^{\text {machine }}\right)<w^{\text {rural }}<w^{\text {domestic }}+u\left(G^{*}\right)$ each increase in the rural wage will induce the patronage politician to increase the provision of $G$ sufficiently to keep the "domestic" and "rural" options equally attractive. It follows that as the rural alternative improves the utility of city residents rises and the utility of politicians falls. For $w^{\text {rural }}$ above $\left[w^{\text {domestic }}+u\left(G^{*}\right)\right]$ the machine politician no longer finds it cost effective to compensate for increased attractiveness of emigration by producing more public goods, and is forced to cut taxes, t. When $w^{\text {rural }}=w^{\text {market }}-G^{*} / N+u\left(G^{*}\right)$ then there are no locational rents in the city and patronage politics cannot exist. There is nothing to steal. When $\mathrm{w}^{\text {rural }}>\mathrm{W}^{\text {market }}-\mathrm{G}^{\star} / \mathrm{N}+$ $\mathrm{u}\left(\mathrm{G}^{*}\right)$ the city itself is no longer viable - all residents leave to seek rural jobs. ${ }^{8}$

\section{THE HISTORICAL RECORD AND THE PRESENCE OF A MACHINE.}

\subsection{Finding the machines}

The model implies that in a machine dominated city we should observe an effective but expensive government: good provision of public goods, but higher taxes and spending, and private payoffs to a large number of voters. To test the model against the experience of American cities during the Progressive era it is necessary to determine which city governments were, and which were not, dominated by political machines. There is no objective variable which can be used to identify a machine dominated government. Instead I have borrowed a technique from modern international comparisons of the impact of corruption the use of subjective estimates of the level of corruption in different countries. For modern studies, scholars generally use measures developed to guide investors (Mauro 1995). For early twentieth century cities I

\footnotetext{
${ }^{8}$ These comparative statics suggest why one should be hesitant to apply the relatively sanguine results of the analysis — that patronage in Progressive era American cities did not suppress the production of public goods - to either national government or to city governments in modern developing countries. In a country with a clearly dominant single city (often the capital) and an extremely low rural wage the legal opportunity to leave the city is not a binding economic constraint because options in the untaxed informal city economy will equal or exceed rural wages. Patronage dependent municipal governments in countries where options outside the city are extremely unpromising will provide some public goods, in order to lower the cost of buying elections, but they will provide less than the socially optimal quantity.
} 
have assembled a subjective measure of machine presence, based on primary sources and on the extensive secondary literature on urban Progressive era politics (Menes 1997).

The early twentieth century urban political machine was a large and visible political institution with a recognizable structure. Three elements can be identified without which the political machine could not function: 1) a "boss," who coordinated the machine's activities in winning elections, paying off members, and running the government; 2) machine "employees," mainly city employees organized into a geographically based hierarchy, who provided favors to voters and collected votes; and 3) election victories based on providing goods and services to individual voters in exchange for votes. The machine structure was determined by the technological demands of vote buying. The machine offered favored voters a range of goods and services, such as jobs, dismissal of a minor infraction of the law, or help with the rent and a scuttle of coal in an emergency (Forthal 1946, among others). The machine structure, with a boss and a large hierarchy of local politicians, was required because providing favors to individual voters in face-to-face exchanges is a labor intensive political technology. The number of votes that any single politician can purchase is limited by the number of voters he can personally know, a number in the thousands even for the best politicians. Control of the city requires tens or hundreds of thousands of votes. Many local politicians must agree to form an alliance in order to win the election. The machine is the organization designed to put together a stable alliance of many local politicians, allowing them to combine their information on voter preferences to win elections. The hierarchical structure of the machine, dominated by a boss who acts as a deal-maker and power-broker between the individual local politicians, divvying up the responsibilities and the spoils, is intended to limit the natural tendency of the politicians to renegotiate the terms of any political alliance. ${ }^{9}$ For my purposes the structure of the machine has the

\footnotetext{
${ }^{9} \mathrm{Political}$ machines varied in their stability. Internal coups were a constant threat to every boss (Brown and Halaby, 1984, 1987). I have previously explored the costs of maintaining internal cohesion and the conditions which favor machine development (Menes 1994, 1997). It was also possible for several competing machines to exist simultaneously in a city.
} 
advantage that such a large political institution was impossible to conceal.

I am able to identify as either "machine dominated" or "known non-machine" the political structure of 44 of the American cities with populations greater than 50,000 in $1900 .{ }^{10}$ To identify a political organization as a machine I had to be able to identify the boss, determine that he gave his political supporters government jobs, and determine that in turn these supporters formed a geographically based network which provided private favors to voters. A number of urban machines emerged during the late 1890s and a significant fraction declined or broke up during or immediately after World War I, making the 20 years from 1900-1920 a natural period to use to identify stable machine organizations. I required that the organization survive at least ten years. To identify a city as machine dominated I had to determine that the city government was largely controlled by a political machine, or several political machines in competition, for at least ten of the twenty years between 1900 and 1920. To identify a city as non-machine I had to determine that political leaders who did not receive important support from patronage-based organizations controlled the city for more than ten years between 1900 and 1920. I limit the sample to cities greater than 50,000 in population because I did not find a city below 50,000 with a machine dominated government. ${ }^{11}$ Table 1 presents the regional breakdown of the sample of cities.

I have previously investigated the relationship between the characteristics of cities and the presence of a machine (Menes 1997). Several conclusions from the previous work are relevant to the

Competing machines could control different parts of a decentralized city government in a de facto truce ( the relationship between New York's Tammany Hall, the dominant Manhattan based machine, and rival machines based in Brooklyn and the Bronx) or could alternate in control of the city (the rival machines of Boston). As long the competing machines fulfilled the minimum requirements established in this paper I code the city as a machine dominated city.

${ }^{10} \mathrm{~A}$ complete list of the cities, with thumbnail sketches of the political histories, can be found in appendix B. Althoughl found the histories of 44 cities, I omit two of these cities from the empirical analysis: Washington DC, as it was not a democracy; and San Francisco, CA, as the effects of the 1906 earthquake dominate the effects of political structure on government performance.

${ }^{11}$ Including cities with population between 30,000 and 50,000 would improve most of the empirical results slightly. Both spending and the provision of durable paving was smaller in the smallest cities. 
present analysis. Machine presence is strongly related to city size - machines develop in the biggest cities - and machine presence is weakly related to the proportion of the population made up of the adult, male children of the foreign born — machines develop in cities with large populations of native born "ethnics." However these are the only two of a large number of characteristics traditionally linked to machine presence for which I could find a statistically significant relationship. Neither the proportion of the population made up of the foreign born nor the importance of manufacturing helps predict the presence of a machine. Machines are also found in all regions of the country except the far West and are found in predominantly Democratic and predominantly Republican communities. Patronage politics appears to have been a flexible political technology, adaptable to a wide range of conditions.

\subsection{The empirical implications of the missing cities}

I have been able to categorize 24 cities as known machine dominated and 18 cities as known nonmachine dominated, but there are 64 cities for which I did not find a good political history spanning the years 1900-1920. During my research it became clear that the cities for which I found political histories were not a random sample of cities. Three factors appeared to predict whether or not I would find a city history: the size of the city (I found large cities), whether or not the years 1900-1920 were a period of economic and demographic growth (I found rapidly growing cities), and whether or not a stable political regime, often a single successful politician, controlled the city government during the years 1900-1920 (I found cities with stable governing regimes). I am not particularly concerned about the selection bias thus introduced into the sample of machine dominated cities. I was trying to find as many of the stable dominant machines as possible. I also explicitly searched the historical literature for references to "machines" and "bosses." However I know that the sample of known non-machine cities is not representative of nonmachine cities in general. The known non-machine sample is dominated by large, rapidly growing cities 
(factors I can and do control for in the regressions), and by cities presided over by popular, successful nonmachine politicians, including several famous "reformers." The known non-machine cities appear to be disproportionately cities with stable and popular governments, which is not a factor I can control for and which is expected to correlate positively with the provision of public goods.

One solution to the problem would be to combine the known non-machine cities and the cities with unknown political histories into a single group and compare the combined sample to the known machine dominated cities. However if I keep the three samples distinct I can turn the biases between the known non-machine and unknown cities to empirical advantage. I do not expect either the known non-machine cities or the unknown cities to show systematic evidence of widespread patronage. A good proxy for patronage therefore should behave the same in the non-machine sample and the unknown sample, and be smaller in both samples than in the known machine cities. I do expect the known non-machine cities and the unknown cities to perform differently as producers of public goods. I expect the popular and long-lasting non-machine regimes to provide approximately the optimal quantity of public goods, while the presumably less popular, less stable unknown regimes will provide too small a quantity of public goods. Comparing the provision of public goods in the machine dominated cities to the known non-machine cities and the unknown cities separately provides a rough test of the prediction that the production of public goods in a machine dominated city will be socially optimal. I expect the known non-machine cities and machine dominated cities to produce similar quantities of public goods.

Technically, I include all three samples in the regression analysis by defining two dummy variables. The first dummy variable identifies a city as either a known political machine or otherwise. The second dummy divides the remaining sample into known non-machine cities and unknown (uncoded) cities. Statistically, it doesn't matter how I define the second dummy (which sample is given the dummy value of 1 and which of 0) but for ease of interpretation of the coefficient on the machine sample I switch dummy 
definitions between the analysis on city spending (government wages and budgets) and on the provision of public goods. In the analyses of wages and budgets I compare the machine dominated cities and the unknown cities to the known non-machine cities - which are the cities I expect to show the fewest signs of patronage. In the analysis of durable paving I compare the machine dominated and the known nonmachine cities to the unknown cities - which are the cities I expect to produce the lowest proportions of durably paved streets.

\section{MACHINE POLITICS AND MUNICIPAL PERFORMANCE}

I propose that the behavior of Progressive era patronage based American urban government is best predicted by model 2 , the model of the patronage dependent government with a footloose tax base. I assume that the non-machine governed cities are ruled by something that can be roughly approximated by the median voter model. I examine three categories of government performance that together provide a test of model 2 against alternative theories and produce minimum estimates of the burden patronage politics imposed on residents in machine-dominated cities. The three choice variables in the model are the vote price, $p_{i}$, the tax level, $t$ (which may include legal and extra-legal exactions), and the level of public goods provision, G. Although there is no record of all the private favors, all the bribes and kickbacks, or even all the public goods provided by any city government, all three variables are reflected in observable government behavior. I use three measures of government performance, the wages of unskilled municipal employees, the city budget, and the proportion of streets paved with durable paving, as proxies for the three choice variables.

There are three alternative theories against which I am testing model 2 . The first alternative theory is the null hypothesis that there is no difference between the cities I have identified as machine and those that are either non-machine or whose political structure is unknown. The second alternative theory is Hays' 
thesis that machine politicians gave their supporters what they wanted, private favors, $\mathrm{p}_{\mathrm{i}}$, while "reform" politicians (machine opponents) responded to their constituencies by producing more public goods, G. (The Hays' thesis does not provide an a priori estimate of the difference in taxes, $t$, between the two types of cities.) The third alternative is that the machine cities are more like model 1 , patronage in a city with a fixed tax base. The second and third alternatives are empirically indistinguishable from each other. Both predict that machine politics will lead to positive payoffs to voters, $\mathrm{p}_{\mathrm{i}}$, and to a lower quantity of public goods, G. Both alternatives, however, can be distinguished from my proposed model, model 2 . Model 2 predicts that the production of public goods, G, will be the same (or higher) in machine dominated cities than in the non-machine cities.

\subsection{Looking for p: Municipal wages and machine presence}

I test for the presence of payoffs to machine supporters, positive $p_{i}$, by examining the wages of city employees in unskilled city jobs in 1909. Patronage jobs, government jobs given to political supporters, were (and are) the lifeblood of patronage politics. ${ }^{12}$ In order for a city job to have political value the recipient of the job must prefer the government job to private sector opportunities. For many jobs the political premium may be hard to discern. A city job can provide a political premium if an individual is hired for a job he would not be able to obtain in the private sector. (The city does not necessarily hire unqualified workers; some individuals may face discrimination in the private sector.) Jobs which include discretionary functions, such as the work of policemen or inspectors, may pay the political premium by providing opportunities for the patronage appointee to extract bribes from citizens, which will not be recorded. But for the large number of city employees who worked at unskilled jobs — digging ditches, sweeping streets, and collecting

\footnotetext{
${ }^{12}$ For example, a survey of 600 precinct captains, the lowest official rank in the political hierarchy of the machine, in three separate machine organizations active in Chicago around the mid 1920s found that $70 \%$ of the precinct captains held government jobs (Forthal 1946).
} 
garbage - the political premium was likely paid by inflating wages. ${ }^{13}$ Unskilled workers were an appealing source of votes for machine politicians because their votes were likely the cheapest votes to buy. Unskilled wages are an appealing place to look for the payoffs. There are few good non-political reason to overpay unskilled city employees. The presence of a premium on municipal wages of unskilled workers is a proxy for $p_{i}$, the price of a vote. ${ }^{14}$

Daily wages for several classes of municipal employees in five city departments (sewers, refuse disposal, street cleaning, dust prevention, and general highways) can be obtained for cities with populations greater than 30,000 in 1909 . The summary statistics for the average daily wages reported for unskilled laborers, by region and by city type for cities with populations greater than 50,000, are presented in table 1. The machine cities paid more, on average, than the non-machine cities in all regions except New England, (in which I found only one known non-machine city). The model, however, does not predict that the absolute levels of municipal wages will be higher in machine cities. Rather, it indicates that the municipal wage will be higher than the corresponding private sector wage in the same city. The proposition is tested by regression analysis, controlling for the private wage rate in the city. The results are reported in table 2. The log of the municipal wage paid to unskilled workers is regressed on proxies for the unskilled wage paid in the private sector and on "machine" and "politically unknown" dummies. The functional form tests for the wage premium as a percentage of the unskilled wage, which assumes the price of a vote is linear in income. The region and the annual wage cost per full time employee in bakeries are used as

\footnotetext{
${ }^{13}$ The other way to pay a bonus to an employee in an unskilled job is to let him shirk. Anecdotal evidence suggests that machine governments did allow some shirking, which produces a downward bias on the observed wage premium in machine cities.

${ }^{14} \mathrm{Patronage} \mathrm{politics} \mathrm{is} \mathrm{not} \mathrm{the} \mathrm{only} \mathrm{political} \mathrm{structure} \mathrm{in} \mathrm{which} \mathrm{city} \mathrm{workers} \mathrm{can} \mathrm{be} \mathrm{a} \mathrm{political} \mathrm{resource} \mathrm{and} \mathrm{hence}$ extract above market wages. However in 1909 there was little opportunity for city workers to develop independent political power. Few unskilled workers had civil service protection and none were unionized; they served at the pleasure of elected politicians or their appointed department heads.
} 
proxies for the private wage. Bakeries were found in all cities, the technology across cities was similar, and the work of bakery employees (not owners) was relatively low skill. ${ }^{15}$ Since bakeries employed women as well as men, whereas the low skill workers employed by municipal departments were almost exclusively men, the proportion of men in the bakery work force in each city is included as a regressor to control for the difference in average labor costs in bakeries due to the different gender ratios in the bakery work force of different cities. Population size and rate of population growth are included as regressors, both because they are correlated with machine presence and because they may change the nature of the private labor market, but neither appear to have had a significant impact on the municipal wage premium for unskilled workers.

There are 105 cities (23 machine, 18 non-machine and 64 politically unknown) with populations greater than 50,000 in 1910 for which both daily unskilled municipal wages and the annual wage per employee in bakeries are reported. For each city, wages could be reported for unskilled workers in up to five departments, for a potential total of 515 observations, but no city reported wages in all five departments. The total number of city-wage observations is 388 and the regression is run on the full sample of 388 wage rates, including dummy variables for the region and for the department reporting the wage. The reported standard errors are White-corrected to correct for city effects. The regression results shown in table 2 indicate that an unskilled municipal employee in a machine city received $8 \%$ more than he would in an otherwise identical city without a machine government. If the municipal worker worked full time then the annual subsidy received was roughly $\$ 50$. Using two dummies to identify the city political structure allows a comparison of both the machine dominated cities and of the unknown cities against the sample of known non-machine cities. As expected, the difference between wages in politically unknown (uncoded)

\footnotetext{
${ }^{15}$ Similar results are found using wages of employees in saw mills if the cities in the Pacific Northwest, where lumber mills were both numerous and unusually large, are omitted.
} 
cities and the known non-machine cities (the omitted category) is not large and is not statistically significant.

Although we reject the null hypothesis that machines did not exist, the wage premium is consistent with all of the alternative theories of machine behavior, model 1 and the Hays thesis, as well as with my proposed model, model 2. I also cannot determine from the regression analysis the true incidence of the patronage wage premium. Did municipal employees in a machine city perform the city functions they were hired to perform? What other services did they provide to city residents? If machine workers spent little of their time on official work, the cost to the city taxpayers depended on the value of the work the machine workers were doing instead. If the patronage employees were busy providing goods and services to their neighbors in exchange for votes, then city residents as a whole were getting some value. If, on the other hand, machine employees were busy gathering information about their neighbors that lowered the price the machine paid for votes, the city residents were worse off. The machine politicians, particularly the boss, were better off. In the next two sections I answer some of the questions raised by the existence of the patronage premium. I find and test proxies for government costs and public goods provision that allow me to distinguish amongst the alternative hypotheses. I leave for future study the question of who got and who paid the patronage wage premium, observing only that $\$ 50$ a year seems a plausible payoff for the political allegiance of an unskilled man and his immediate family and friends.

\subsection{Looking for t: Municipal budgets and machine presence}

I turn now to look for evidence of increased costs, higher $t$, in the patronage dependent governments. According to the predictions of both model 1 and model 2 a machine government imposes a heavier financial burden on taxpayers than a non-machine government. The machine politicians are paying to buy votes, paying to provide public goods, and stealing as much as possible without destroying the tax 
base. I use the per capita city budgets, total and by department, as proxies for government revenue, t. Using the official budget as a measure of the cost of government biases the empirical work against finding patronage-dependent costs. Many exactions, such as bribes paid to city politicians and bureaucrats or profits made from dealing on insider information or from manipulating local markets through regulation, never show up in the official budget (Menes 1997). Some of the cost inflation, however, will show up in the budget, such as the funds needed to pay for patronage wage premiums and for inflated government contracts. Therefore comparing city budgets provides a test biased against finding a machine effect and produces a minimum estimate of the financial burden of the machine ${ }^{16}$ The OLS regressions of municipal spending run on the cross section of cities, as shown on table 4, find the cities with machine dominated governments spent 18\% more per capita on municipal expenses, roughly $\$ 5.00$ per city resident per year, or about three days' wages for an unskilled worker, in the average machine city.

Simultaneity is a more serious problem for the analysis of city spending than for the analysis of municipal wages. It is difficult to come up with alternative explanations for the wage premium — the residents of a city never want to overpay city workers. But unobserved city characteristics might contribute to differences in demand for city services and hence to differences in city budgets. These unobserved variables might also be correlated with political structure. The optimal solution to the statistical problem would be to use instruments for political structure that are not related to the supply or demand for city services. Unfortunately it is unlikely that such instruments existed and even less likely that any were recorded. However I can increase confidence in the conclusion that the apparent machine premium

\footnotetext{
${ }^{16}$ There is one caveat to this conclusion. There were corrupt non-machine city governments, too. If all governments used the same tactics to extract rents from citizens then corruption in non-machine cities biases down the empirical estimate of the machine premium. However, if non-machine corruption was more likely to be off-budget (for example, more bribes for changing building codes and fewer kickbacks on city contracts) then a higher premium on the municipal budget in machine cities would not necessarily indicate that the corrupt machine cities were more costly than the corrupt non-machine cities. I have no a priori reason to suspect this problem, but the possibility points out the importance of research into the techniques of political graft.
} 
observed in the city budget is due to machine presence by examining a breakdown of city spending by department. Some municipal departments were better suited to patronage-dependent cost inflation than others. As Teaford observes, patronage and corruption were concentrated in departments where the skill of workers was the least important, where the elected officials controlled hiring directly, and where the machine valued employing loyal workers. Departments where high skills were demanded, or where important and technologically advanced public goods were produced, were likely to be spared patronage appointments and sweet-heart contracts to unqualified contractors(Teaford 1984). It is unlikely that unobserved variables would produce a pattern of demand for city services across the different departments which would mimic the spending pattern induced by the demands of patronage. I do not argue that bureaucratic professionals would never inflate costs but rather that they would do so more or less equally across departments.

Tables 5 and 6 present OLS cross section regressions of average per capita spending on current expenses in five separate departments: general administration, protection, health, highways, and education. ${ }^{17}$ The point estimate for the machine premium is largest in the departments of health and sanitation (19.8\%), protection (18.6\%) and general administration (33.9\%). ${ }^{18}$ These estimates of machine premia by department are consistent with the notion that machines raise the cost of city government through patronage and theft, while leaving output of public goods unaffected. The large effect, 33.9\%, observed in the budget for general administration, suggests we are observing the effect of patronage hires on the city budget. The mayor, the council members, and the judges were the machine. In general administration they hired patronage workers directly, without having to go through the appointed head of

\footnotetext{
${ }^{17}$ Current expenses are reported for a total of seven departments. The omitted departments are recreation and miscellaneous. For neither of these divisions is the machine a statistically significant predictor of expenses, but neither do the remaining regressors do not capture much of the variation in spending between cities in these departments.

${ }^{18}$ The point estimate of machine impact in the departments of health and sanitation is not statistically significant.
} 
another department. Many of the jobs were relatively unskilled, or at least required skills which had traditionally been called for in government, such as legal training, not the new professional skills required of civil engineers, certified teachers, or social workers. Control of the administration and of the courts was also important to machine control because many of the activities of machine politicians were illegal. The individuals working for the courts, for the mayor, and for the legislators observed the activities of machine politicians most closely and had the primary responsibility for enforcing regulations and laws banning corrupt practices. They would have been paid a hefty premium to ensure that they ignored their official responsibilities. A similar argument may be made for the police department.

I expect the machine premium to be smaller, or non-existent, in the budgets of other departments. The regressions indicate that the machine had little effect on current expenditures in the department of highways and a negative effect, if anything, on spending on education, (the machine coefficient on education spending is not statistically significant). Both school systems and highways departments were adopting new technologies and expanding the kinds of goods and services provided to the public. Although there were plenty of low-skilled jobs in schools and (especially) in highway departments, both departments required educated, professional management, people selected for skills as much or more than for political loyalty. I do not want to read too much into the negative point estimate on school spending. Some of the real factors decreasing demand for public schools were positively related to machine presence - for example, cities with a large proportion of native born Americans with foreign born parents were often cities with large parochial school systems, which decreased the demand for public schools. But on the other hand school systems were not particulary suited to patronage. In many cities the Board of Education was an independent unit of government, with its own elected officials and often its own ability to levy taxes. A machine that controlled the central government may or may not have controlled the Board of Education. Many teachers were also unmarried women and in most cities women did not vote. 
The analysis of city budgets confirms that not only did patronage exist but that it inflated taxes and city spending. However it is still not possible to determine, from spending data, whether or not patronage had an impact on the production of public goods.

\subsection{Looking for G: Machine Presence and durable paving}

Paving as a measure of public goods provision

The proportion of streets surfaced with durable paving, paving with asphalt, stone, or brick on a concrete foundation, can be taken as a measure of the quantity of public goods provided to city residents. The quantity and quality of many of the goods and services provided by local government might be expected to provide measures of the provision of public goods, but in practice the production of public goods is nearly as difficult to observe as outright graft, and harder to measure than the effects of patronage employment. ${ }^{19}$ We can measure inputs, the number of teachers or policemen, but it is harder to measure the outputs, education and safety, and even harder to determine if variations between cities reflect differences in costs, efficiency, or demand. Physical outputs are easier to measure, but today most cities meet essentially all of the demands for physical infrastructure — all roads are paved, all residences are connected to the city water and sewer systems. In the first decade of the twentieth century, however, there was significant variation in the provision of measurable physical infrastructure. Of all of the new public goods - water, sewers, street railways, high schools, ports, and bridges — the proportion of city streets paved with durable paving provides the best measure of the success of local government at providing public goods. Durable paving was costly, important to city residents, measurable, and measured, the result of recent government decisions, a public, not private, good, provided only by government, and neither

\footnotetext{
${ }^{19}$ Difficulty in evaluating the performance of government plagues much of the research on urban government, not just research on machine politics or corruption. See the review of the empirical Tiebout hypothesis literature by Keith Dowding, Peter John and Stephen Biggs (1994).
} 
unusually resistant to nor unusually distorted by graft. In the average city only about $25 \%$ of all the streets were paved with a durable surface material and there was considerable variation between cities (table 7). And both demand and costs were in large part determined by city characteristics such as size, density, and average wage rates that were observable, were observed, and can be controlled for in empirical analysis.

Streets have aspects of both public and private goods, but, as argued by Clay McShane, durable paving was a largely public good in 1900 (1979). Durable paving had, for many city residents, the qualities of a private bad. Commercial traffic, heavy wagons with thin, iron rimmed wheels, rapidly damaged dirt roads and non-durable gravel or macadam paving. Commercial traffic was noisy, dirty and dangerous. In a city in which most streets could not handle commercial wagons, upgrading the paving on a residential street increased traffic flow through the city but decreased the quality of life for abutters by encouraging teamsters to use the street. The conflict between public good and private bad is likely to have been greatest in the densely populated residential neighborhoods close to the central business district, where the street served as an important social and retail space. Row houses and tenement flats had little or no open land of their own and much neighborhood activity occurred in the streets. If machines favored the poorest voters over city-wide commercial interests they might be expected, as Hays predicted, to stint on durable paving.

In the model the public good, $G$, is assumed to be a consumption good (like a park or library), but paved roads are an intermediate input, not a consumption good. Hays does not distinguish between public consumption goods and public intermediate inputs, he predicts that patronage dominated cities produced less of both. The issue is only important if we are trying to distinguish between model 1 and model 2 . Although the productive sector is not explicitly modeled, a trivial extension of the models would show that in an open city, model 2, a kleptocratic machine politician will provide the optimal quantity of all public goods, both final consumption goods and intermediate goods, because they all have the same impact on the 
sustainable tax rate. The kleptocratic boss of a closed city, model 1, however, will treat some intermediate input public goods differently from consumption public goods. If a public good is an input only into the production of goods and services sold outside the city then the kleptocrat will provide the optimal quantity of that public good. The export market plays the same role in extension of model 1 as the open boundary and the movement of taxpayers does in the original version of model 2; anything that lowers the production costs of an export good increases the tax that the government can levy on the producer without driving him out of business. It therefore would be impossible to distinguish between model 1, a closed city, and model 2, an open city, if durable paving were purely an input into the production of export goods.

However the difference between intermediate input and final consumption good is not empirically important for my analysis, for two reasons. First, distinguishing between model 1 and model 2 is not the main purpose of the analysis. I know that labor could, and did, move freely into and out of American cities, so I am relatively secure in the conclusion that model 2 is the appropriate model. I am more interested in testing model 2 against alternatives found in the historical literature. Second, if I were concerned with distinguishing between models 1 and 2, durable paving would be an appropriate test because it was not an input into export goods in American cities during the year 1900-1910. It was in input into the production of domestically consumed goods and services. Public goods which are inputs into domestically consumed goods and services are theoretically indistinguishable from public consumption goods; they increase the well-being of city residents but they only form part of the taxable sector if the residents can vote with their feet.

Today it is impossible to determine the extent to which the road system is an input into locally consumed goods compared to exported goods. Factories with national markets, supermarkets responding to local demand, and commuters working for every sector in a city's economy are all dependent on the road system. However in 1900 or 1910 most of the demand for durably paved roads came from a much 
narrower economic sector — local retail trade. Most people moved on foot or by street-car. Goods moved into and out of the city by rail, not on roads. Every factory of any size selling to national markets needed rail access, not road access. The road system of a city did not link up to a national or even a statewide system of roads, and if it had there were no trucks, only wagons drawn by horses or other draft animals. For shipments between cities trains were cheaper. Consumer goods, food, ice, coal, clothes, furniture and all the other physical demands of the urban household, however, moved within the city from wholesale warehouse to store and from store to home in wagons pulled over city streets. Paved roads in 1900 were intermediate inputs to the production of locally consumed goods and their provision had the same effect on the taxpayer's utility, and willingness to move, as did providing public consumption goods like parks and libraries.

The proportion of streets with durable paving, not the overall mileage, is the best measure of provision of paving to city residents. The total mileage of streets in a city was not a choice variable for the city government. New streets were developed as city growth demanded. Most new streets, especially residential streets, were unpaved or paved with a gravel pavement of some variety on a dirt foundation. City characteristics, especially the population and density of the city, then determined what proportion of the existing streets it would have been optimal to pave with durable surfacing.

The final assumption of the empirical work is that once I control for population, area, wealth, and demographic characteristics of the city, the higher the proportion of city streets that are durably paved the closer the city is to the optimal provision of paving - no cities are over-producing paving. Historically, the explosion of the automobile and truck fleets during the second decade of the twentieth century ensured that no city regretted a heavy investment in paving before 1910. It is possible, however, that some city governments thought they were putting in too much durable paving, although even before the widespread use of the auto the demand for paving was rising rapidly (McShane 1979). My concern is that the machine 
dominated city government may have been trying to over-invest in paving, because paving projects may have been unusually well suited to graft. I should stress that there is no evidence that paving contracts were more prone to graft than other forms of government spending, nor that it was necessary to do excessive paving in order to pad paving contracts. (And there was an abundance of paving to be done.) However it is good to have at least a rough test for the "optimality" of the quantity of paving in machine dominated cities. Such a test is provided by the division of the sample of cities in which I did not find machines into cities with known political histories and cities for which the political histories are not known. As I have previously argued, if the machine cities are doing their best to provide the optimal levels of paving they should resemble the known non-machine cities and both the machine cities and the known non-machine cities should lead the mystery cities in proportion of durable paving. As can be seen in figure 1, it might at first appear that in fact the machine cities are providing too much paving. In raw proportions they lead both other samples in the provision of paving. However, as we shall see in the regression analysis, the apparent lead of the machine cities is entirely accounted for by their geographic location in the older, colder Northeast and their larger population.

\section{The provision of paving in cities}

Figure 1 presents the provision of paving in the three samples of cities: machine, known nonmachine, and politically unknown. As shown, the machine cities paved a higher proportion of their streets, over a third, than did the two other kinds of cities, with the known non-machine cities paving a little under a quarter and the cities with unknown political structure paving less than a fifth of all of their street-miles. Although the link between the proportion of paving and the services provided to city residents by the paving is closer than with many other kinds of public infrastructure, weather, population, the physical size of the city, the prevailing wage rate, and the age of the city affected both the supply of and the demand for 
durably surfaced roads. In the regression analysis I control for a range of supply and demand shifters (table 8). Although, as shown in the first regression, population and area of the city matter, the story told by the regression analysis is not much different from the graphical analysis. The machine dominated cities are paving about $11 \%$ more of their miles of roadways. As the sample average is only $23.5 \%$ of all roads paved with durable paving, the machine cities are paving almost $50 \%$ more of their streets than the average city. In the national sample the known non-machine cities lag the machine cities by a little over $4 \%$, although the difference is not statistically significant.

The relationship between paving and machine presence in the national sample may reflect relationships between machine presence and city characteristics that are also related to the provision of paving. Two issues are of concern - non-linearities in the relationship between city size and machine presence and differences in the supply and demand functions for paving related to the climate and age of the city. The first graph and the results of the first regression may reflect the large number of very large cities dominated by machine politics or the presence of a large number of machines in the older, colder cities in the Mid-Atlantic, East North Central, and West North Central census regions. To determine if such differences alter paving provision the empirical analysis of paving is repeated three sub-samples, divided by size and region. Because almost all the cities over 300,000 are machine dominated and these largest cities might have unusually high demands for paving, I repeat the graphical and regression analyses on the medium sized cities between 50,000 and 300,000. Because the machine form is most prevalent in the cities of the Northeast where older cities and colder climates might be expected to increase the demand for and provision of paving, I repeat the regression analysis on cities found in the Mid-Atlantic, East North Central and West North Central. ${ }^{20}$ Finally, I combine these two restrictions to examine the importance of the

\footnotetext{
${ }^{20}$ The cities in New England resisted durable paving for reasons I have not yet been able to track down in the literature. Except for Boston, the New England cities depended largely on non-durable, gravel based paving. Because of the regional difference between New England and the rest of the Northeastern states I omit the New England states from the sub-
} 
presence of a machine in the medium sized Northeastern cities. The regressions reported for all four samples are extremely consistent. Population and area are the most important and significant predictors of the demand for paving, and their impact does not seem to vary by region, or be significantly different in the smaller cities. The consistency of the coefficients on the non-political regressors in all four samples provides further support for the choice of durable paving as a basis of comparison of the provision of public goods across cities.

The results on the political coefficients, machine and non-machine, are of the greatest interest. As shown in table 8 , the machine dominated city governments provide as much paving as the known nonmachine cities and considerably more paving than the cities whose political structure is not known. The only significant change between the analysis of the national population of cities and the three sub-samples is an improvement. The difference between the machine dominated and the known non-machine cities, never statistically significant, basically disappears in the sub-samples. In the sample of medium sized Northeastern cities the known non-machine cities actually provide the highest proportion of paving of all three kinds of cities (although the difference is a statistically and economically insignificant $0.2 \%$ ) In all three sub-samples the known non-machine cities provide significantly more paving than the cities with unknown political structure, both in the economic and in the statistical sense. As I have already argued, stable and popular administrations, presumably honest and effective, tend to show up disproportionately in the population of known non-machine city governments. It is reassuring that these known non-machine cities perform, in the provision of durable paving, like the machine dominated cities.

The results support my theoretical framework, the second model with mobile taxpayer/voters, in

sample of "Northeastern" states, to confirm that the apparent effects are not driven by the New England cities. Including New England cities would strengthen my conclusions. I present the results for regressions on sub-samples in order to show the stability of the relationship of all variables to durable paving across size and region. It would not be incorrect to run these regressions using regional dummies and ignoring the potential non-linearities in the effect of population size, although a priori such a functional form might not have been appropriate. 
comparison to either the Hays' thesis or the first model, with an immobile tax base. The empirical analysis suggests that machine dominated city governments produce the optimal quantity of durable paving, or at least as close to optimal as the leading non-machine cities. If either the Hays' thesis or model 1, with the effectively immobile tax base, were correct then we would expect that the known non-machine cities would provide a higher level of paving and the provision of paving in machine cities should resemble the provision in the politically unknown cities, or worse. But machine politics, far from suppressing the provision of durable goods, appears to encourage their provision. The presence of a machine appears to boost the proportion of durable paving by more than $10 \%$ of all street surfaces compared to population of cities with unknown political histories. Since the average proportion of paving is between $20 \%$ and $40 \%$ in all samples, the residents in machine cities receive, all else held constant, a quarter to a half more paving. On the other hand there is little evidence of too much paving. The machine cities are indistinguishable, statistically, from the known non-machine cities. The conclusion, therefore, is exactly the implication derived from the model: the machine cities are as generous as the "best" of the rest of the city governments at providing public goods. They perform significantly better than the average city government.

\section{CONCLUSIONS AND FUTURE DIRECTIONS}

I have found that, despite the claims of contemporary political opponents and later scholars, patronage politics in Progressive era American cities did not cripple the performance of government. There is no evidence that patronage-ridden city governments underperformed non-machine dominated city governments in the provision of at least one important public good, durable paving, and some evidence that the machine cities outperformed the average city government. I do not, however, conclude that corruption did not matter in American cities, nor that corruption does not distort economic and political development in modern democracies. The inflated wages and budgets suggest that corruption did cost tax- 
payers, even if it did not distort the provision of public goods. Perhaps more important, the analysis, based on the model and the empirical results, confirms that the effect of rent-seeking behavior depends on both the political structure produced by patronage and on the economic and legal framework within which patronage dependent politicians function. In American cities, open boundaries and high wages outside the city combined to constrain kleptocratic governments, but for a patronage dependent national government, or for city government embedded in a country with an extremely low rural wage, vote-buying might allow the government to cut back on the provision of public goods.

I cannot conclude with a simple policy prescription for limiting the impact of corruption in modern democracies, but the experience of American cities suggests that legal and economic constraints may be as effective as political reform in controlling the burden that corruption places on an economy. This study of American cities also suggests that rational choice models are effective tools for predicting possible relationships between corruption and government performance and for producing testable hypotheses. The results suggest that mobility and competition between political units can mitigate the impact of rent-seeking. The results imply an additional explanation why open borders appear, empirically, to encourage economic growth. Classical economic theory predicts that free trade leads to efficient use of inputs. Modern work predicts that the competition engendered by free trade also limits monopoly and encourages innovation in the private sector. This study proposes a third possible mechanism for the role of open borders in encouraging economic growth - movement of inputs and outputs across political boundaries may encourage venal governments to behave better. 


\section{REFERENCES}

Addams, J. 1898. Why the ward boss rules. Outlook 58 (April): 879-82.

Ades, A. F. and E. L. Glaeser. 1993. Trade and circuses: Explaining urban giants. Paper presented at the Joint Harvard-MIT Research Training Group in Positive Political Economy Seminar, December, at MIT, Cambridge.

Allswang, J. H. 1977. Bosses, machines, and urban voters: An American symbiosis. Port Washington, NY: Kennikat Press.

Banfield, E. C. and J. Q. Wilson. 1963. City politics. Cambridge: Harvard University Press.

Baum, D. and W. R. Miller. 1993. Ethnic conflict and machine politics in San Antonio, 1892-1899. Journal of Urban History 19 (Aug): 63-84.

Bean, P. A. 1994. The Irish, the Italians, and machine politics, a case study: Utica NY (1870-1960). Journal of Urban History 20 (Feb): 205-239.

Bean, W. 1968. Boss Ruef's San Francisco. Berkeley: University of California Press.

Berner, R. C. 1991. Seattle 1900-1920: From boomtown, urban turbulence, to restoration. Vol. 1, Seattle in the twentieth century. Seattle: Charles Press.

Blackford, M. G. 1968. Reform politics in Seattle during the Progressive era, 1902-1916. Pacific Northwest Quarterly 59 (Oct): 177-185.

Blewett, M. 1976. The mills and the multitudes: A political history. Pp. 161-189 in Cotton was king: A history of Lowell Massachusetts, ed. A. L. Eno, Jr. Lowell, MA: Lowell Historical Society.

Bodenhamer, D. G. and R. G. Barrows, eds. 1994. The encyclopedia of Indianapolis. Bloomington: University of Indiana Press.

Booth, D. E. 1985. Municipal socialism and city government reform: The Milwaukee experience, 1910-1940. Journal of Urban History 12 (Nov): 51-74.

Boulay, H. and A. DiGaetano. 1985. Why did political machines disappear? Journal of Urban History 12 (Nov): 25-49.

Bridges, A. 1984. A city in the republic: Antebellum New York and the origins of machine politics. Cambridge: Harvard University Press. 
Brown, M. C. and C. N. Halaby. 1984. Bosses, reform, and the socioeconomic bases of urban expenditure, 1890-1940. Pp. 69-99 in The politics of urban fiscal policy, ed. T. D. McDonald and S. K. Ward. Beverly Hills: Sage.

—. 1987. Machine politics in America, 1870-1945. Journal of Interdisciplinary History 17 (Winter): 587-612.

Bryce, J. 1919. The American commonwealth. New edition. Vol. 2. London: MacMillan.

Buenker, J. D. and N. C. Burckel. 1980. Progressive reform: A guide to information sources. Detroit: Gale Research Co.

Buenker, J. D. and E. R. Kantowicz, eds. 1988. Historical dictionary of the progressive era, 1890-1920. Westport, CT: Greenwood Press.

Cain, Louis P. and Elyce J. Rotella. 1990. Urbanization, sanitation, and mortality in the Progressive era, 1899-1929, mimeo from authors.

Civil Service Assembly. 1937. Civil Service Agencies in the United States: A 1937 Census. np: Civil Service Assembly of the United States and Canada.

Callow, A. B., Jr., ed. 1976. The city boss in America: An interpretive reader. New York: Oxford University Press.

Crooks, J. B. 1968. Politics and progress: The rise of urban progressivism in Baltimore, 1895-1911. Baton Rouge: Louisiana State University Press.

Dahl, R. Who Governs? New Haven: Yale University Press.

DeLong, J. B. and A. Shleifer. 1992. Princes and merchants: City growth before the industrial revolution. Paper presented at the Harvard Economic History Workshop, Spring, at Harvard University, Cambridge.

De Soto, Hernando. 1989. The Other Path. June Abbott, trans., London: I.B. Tauris.

DiGaetano, A. 1991. Urban political reform. Did it kill the machine? Journal of Urban History 18 (Nov): 37-67.

Dorsett, L. W. 1968. The Pendergast machine. New York: Oxford University Press. 1976. The queen city: A history of Denver. Boulder, CO: Pruett Publishing Co. 
Ebner, M. 1972. The historian's Passaic, 1855-1912: A research model of New Jersey's urban past. Pp.10-35 in New Jersey since 1860: New findings and interpretations, ed. E. H. Foster and G. W. Clark. Trenton: New Jersey State Historical Commission.

Eggert, G. G. 1993. Harrisburg industrializes: The coming of factories to an American community. Univ. Park, PA: Penn State University Press.

Elenbaas, J. D. 1974. The boss of the better class: Henry Leland and the Detroit Citizens League, 1912-1924. Michigan History 58: 102-150.

Eno, A. L., Jr. 1976. Cotton was king: A history of Lowell Massachusetts. Lowell: Lowell Historical Society.

Erie, Steven P. 1988. Rainbow's end: Irish-Americans and the dilemmas of urban machine politics, 1840-1985. Berkeley: University of California Press.

Forthal, S. 1946. Cogwheels of democracy. New York: William Frederick Press.

Foster, E. H. and G. W. Clark, eds. 1976. Hoboken: A collection of essays. New York: Irvington.

Foster, M. S. 1968. Frank Hague of Jersey City: 'The boss' as reformer. New Jersey History 86 (2): 106-117.

Gimpel, J. 1994. Reform-Resistant and Reform-Adopting Machines: The Electoral Foundations of Urban Politics, 1910-1930. Political Research Quarterly 46 (June): 371-382.

Goldin, C. D. and H. Rockoff, eds. 1992. Strategic factors in nineteenth century American economic history. Chicago: University of Chicago Press.

Goldin, C. D. and L. F. Katz. 1997. Why the United States led in education: Lessons from secondary school expansion, 1910 to 1940. NBER Working Paper Series, 6144.

Goldman, M. 1983. High hopes: The rise and decline of Buffalo, New York. Albany: State University of New York Press.

Gosnell, Harold F. [1937] 1968. Machine politics: Chicago model. Reprint, Chicago: University of Chicago Press.

Harris, C. V. 1977. Political power in Birmingham, 1871-1921. Knoxville: University of Tennessee Press.

Hays, S. 1964. The politics of reform in municipal government in the Progressive era. Pacific Northwest Quarterly 55 (Oct): 157-169.

Heidenheimer, et al., eds. 1989. Political corruption. New Brunswick, NJ: Transaction. 
Hoffecker, C. E. 1983. Corporate capital: Wilmington in the 20th century. Philadelphia: Temple University Press.

Hofstadter, R. 1962. The age of reform. London: Jonathan Cape.

Holli, M. and P. d'A. Jones, eds. 1981. Biographical dictionary of American mayors, 1820-1980. Westport, CT: Greenwood Press.

Judson, William Pierson. 1902. 1906. 1909. City roads and pavements suited to cities of moderate size. New York: Benthuysen and sons.

Key, V. O., Jr. 1936. The techniques of political graft in the United States. Chicago: University of Chicago Libraries.

Krueger, A. O. 1993. Virtuous and vicious circles in economic development. Paper presented the Political Economy Lecture Series, February, at Harvard University, Cambridge.

Lay, M.G. 1992. Ways of the world: A history of the world's roads and of the vehicles that used them. New Brunswick: Rutgers University Press.

McDonald, T. D. and S. K. Ward, eds. 1984. The politics of urban fiscal policy. Beverly Hills: Sage.

McGuire, M. C. and M. Olson Jr. 1995. The economics of autocracy and majority rule: The invisible hand and the use of force. Paper presented at the MIT Public Finance Seminar, Fall, at the Massachusetts Institute of Technology, Cambridge.

McShane, Clay. 1979. Transforming the use of urban space: A look at the revolution in street pavements, 1880-1924. Journal of Urban History 5 (May): 279-307.

_ 1994. Down the asphalt path: the automobile and the American city. New York: Columbia University Press.

Mauro, P. 1995. Corruption and growth. Quarterly Journal of Economics 110 (Aug): 681-712.

Menard, O. D. 1989. Political bossism in mid-America: Tom Dennison's Omaha, 1900-1933. Lanham, MD: University Press of America.

Menes, R. 1997. Public goods and private favors: Three essays on patronage politics in American cities during the Progressive era, 1900-1920. Ph.D. dissertation. Harvard University.

Merton, R. S. 1957. The latent functions of the machine. Reprinted in Urban bosses, machines, and Progressive reformers, ed. Bruce Stave. 1972: 27-37. Lexington: D. C. Heath. 
Miller, W. D. 1957. Memphis during the Progressive era: 1900-1917. Memphis, TN: Memphis State University Press.

Murphy, K. M., Andrei Shleifer and Robert Vishny. 1993. Why is rent seeking so costly to growth? American Economic Review 83 (May): 409-414.

Newfield, J. and Wayne Barrett. 1988. City for sale: Ed Koch and the betrayal of New York. New York: Harper and Row.

Olson, M. 1991. Autocracy, democracy, and prosperity. In Strategy and choice, ed. R. J. Zeckhauser. Cambridge: MIT Press.

Primm, J. N. 1981. Lion of the valley: St. Louis, Missouri. Boulder, CO: Pruett Publishing.

Rauch, J. E. 1995. Bureaucracy and economic growth: Theory and evidence from U.S. Cities during the Progressive era. American Economic Review. 85(Sept.):968-79.

Reid, J. D., Jr. and M. M. Kurth. 1992. The rise and fall of urban political patronage machines. Pp. 422-445 in Strategic factors in nineteenth century American economic history, ed. Claudia D. Goldin. Chicago: University of Chicago Press.

Rice, B. R. 1977. Progressive cities. Austin: University of Texas Press.

Riordan, W. L. [1905] 1991. Plunkitt of Tammany Hall. Reprint, New York: Meridian.

Robinson, F. S. 1977. Machine politics: A study of Albany's O'Connells. New Brunswick, NJ: Transaction Books.

Shiesl, Martin J.1977. The Politics of Efficiency. Berkeley: University of California Press.

Scott, J. C. 1969. Corruption, machine politics and social change. American Political Science Review. 63:4, 1142-1159.

Sealander, J. 1988. Grand plans. Lexington: University of Kentucky Press.

Shefter, M. 1978. The electoral foundations of the political machine: New York City, 1884-1897. In The history of American electoral behavior, ed. J. H. Silbey. Princeton: Princeton University Press.

Shleifer, A. and R. W. Vishny. 1993. Corruption. Quarterly Journal of Economics. 108 (Aug): 599-617.

Silbey, J. H. et al., ed. 1978. The history of American electoral behavior. Princeton: Princeton University Press. 
Silvia, P. T., Jr. 1973. The spindle city: labor, politics, and religion in Fall River, Massachusetts, 1870-1905. Ph.D. diss., Fordham University.

Stave, B. M., ed. 1972. Urban bosses, machines, and Progressive reformers. Lexington: D.C. Heath.

Steffens, L. [1904] 1957. The shame of the cities. Reprint, New York: Hill and Wang.

Stinchcombe, J. L. 1968. Reform and reaction: City politics in Toledo. Belmont, CA: Wadsworth.

Stone, H. A., D. K. Price and K. H. Stone. 1940. City manager government in nine cities. Chicago: Social Science Research Council.

Teaford, J. 1984. The Unheralded Triumph.

Tiebout, C.M. 1956. A pure theory of local expenditures. The Journal of Political Economy. 64(Oct): 416-424.

Thompson, F.M.L. 1970. Victorian England: The horse-drawn society. London: Bedford College, University of London.

Travis, A. R. 1974. Mayor George Ellis: Grand Rapids political boss and Progressive reformer. Michigan History 58:101-30.

U.S Bureau of the Census. 1900. Twelfth Census: Census of Population. Vol. 1, Population. Washington, DC: Government Printing Office.

- 1905. Statistics of cities having a population of over 25,000: 1903 and 1904. Washington, DC: Government Printing Office.

—. 1907. Statistics of cities having a population of over 30,000: 1905. Washington, DC: Government Printing Office.

-1909a. Statistics of cities having a population of over 30,000: 1907. Washington, DC: Government Printing Office.

1909b. Thirteenth census: Census of manufactures. Vol. 9, Manufacturing industry by state and city. Washington, DC: Government Printing Office.

_ 1910a. Thirteenth census: Census of population. Vol.1, Population. Washington, DC: Government Printing Office.

_. 1910b. Thirteenth census: Census of population. Vol. 3, Occupations. Washington, DC: Government Printing Office. 
- 1913a. General statistics of cities having a population of over 30,000: 1909. Washington, DC: Government Printing Office.

- 1913b. Financial statistics of cities having a population of over 30,000: 1909. Washington, DC: Government Printing Office.

-1924. Financial statistics of cities having a population of over 30,000: 1922. Washington, DC: Government Printing Office.

Wallis, J. J. 1993. Form and function in the public sector: State and local government in the United States, 1902-1982. Paper presented at the Development of the American Economy Program Meeting at the National Bureau of Economic Research, March, Cambridge.

Weiss, N. J. 1968. Charles Francis Murphy, 1858-1924: Respectability and responsibility in Tammany Politics. Northampton, MA: Smith College Press.

Wiebe, R.H. 1967. The search for order, 1877-1920. New York: Hill and Wang.

Wilson, J. Q. 1961. The economy of patronage. Journal of Political Economy 69 (Aug): 369-380.

Wright, W. C., ed. 1972. New Jersey since 1860: New findings and interpretations. Trenton: New Jersey Historical Commission.

Zeckhauser, R. J., ed. 1991. Strategy and choice. Cambridge: MIT Press. 
TABLE 1-AVERAGE DAILY MUNICIPAL WAGES OF UNSKILLED WORKERS (IN DOLLARS)

CITIES WITH POPULATION GREATER THAN 50,000 IN 1910

WITH AND WITHOUT MACHINE POLITICS BETWEEN 1900 AND 1920

\begin{tabular}{|c|c|c|c|c|}
\hline & All cities & $\begin{array}{c}\text { Machine } \\
\text { cities }\end{array}$ & $\begin{array}{c}\text { Non-machine } \\
\text { cities }\end{array}$ & $\begin{array}{c}\text { Not } \\
\text { categorized }\end{array}$ \\
\hline All Regions & $\begin{array}{l}1.88(.31) \\
105 \text { cities }^{*}\end{array}$ & $\begin{array}{l}1.97(.26) \\
23 \text { cities }^{*}\end{array}$ & $\begin{array}{l}1.81(.38) \\
18 \text { cities }\end{array}$ & $\begin{array}{l}1.87(.30) \\
64 \text { cities }\end{array}$ \\
\hline New England & $\begin{array}{l}1.98(.25) \\
19 \text { cities }\end{array}$ & $\begin{array}{l}1.97(.26) \\
2 \text { cities }\end{array}$ & $\begin{array}{l}2.31 \\
1 \text { city }\end{array}$ & $\begin{array}{l}1.95(.25) \\
16 \text { cities }\end{array}$ \\
\hline $\begin{array}{l}\text { Mid Atlantic, East- } \\
\& \text { West- North } \\
\text { Central }\end{array}$ & $\begin{array}{l}1.83(.23) \\
58 \text { cities* }\end{array}$ & $\begin{array}{l}1.97(.25) \\
16 \text { cities*}^{*}\end{array}$ & $\begin{array}{l}1.76(.21) \\
9 \text { cities }\end{array}$ & $\begin{array}{l}1.78(.20) \\
33 \text { cities* }^{*}\end{array}$ \\
\hline $\begin{array}{l}\text { Mountain and } \\
\text { Pacific }\end{array}$ & $\begin{array}{l}2.48(.20) \\
8 \text { cities }\end{array}$ & $\begin{array}{l}2.50 \\
1 \text { city }\end{array}$ & $\begin{array}{l}2.47(.04) \\
2 \text { cities }\end{array}$ & $\begin{array}{l}2.47(.27) \\
5 \text { cities }\end{array}$ \\
\hline $\begin{array}{l}\text { South Atlantic and } \\
\text { East South Central }\end{array}$ & $\begin{array}{l}1.60(.27) \\
14 \text { cities }\end{array}$ & $\begin{array}{l}1.71(.07) \\
3 \text { cities }\end{array}$ & $\begin{array}{l}1.32(.16) \\
3 \text { cities }\end{array}$ & $\begin{array}{l}1.67(.29) \\
8 \text { cities }\end{array}$ \\
\hline $\begin{array}{l}\text { West South } \\
\text { Central }\end{array}$ & $\begin{array}{l}1.92(.20) \\
6 \text { cities }\end{array}$ & $\begin{array}{l}2.00 \\
1 \text { city }\end{array}$ & $\begin{array}{l}1.83(.29) \\
3 \text { cities }\end{array}$ & $\begin{array}{l}2.00(0.0) \\
2 \text { cities* }^{\star}\end{array}$ \\
\hline
\end{tabular}

Notes: 105 cities with population greater than 50,000 in 1910. Mean wages in dollars per day. Standard deviations in parentheses. Mean wages are averages of city averages, not weighted by population. See text and appendix B for explanation and sources of the city categories; see appendix A for other variables. The regional classifications are the standard Census classifications.

*The full sample contains 106 cities. Philadelphia, a machine dominated city, did not report wages of municipal workers and hence is excluded from this table and from the analysis of daily wages (table 2). Philadelphia is included in the analysis of city budgets, but three small "not categorized" cities, one in the Mid-Atlantic and two in the West South Central, did not report complete budgetary information for the year 1905-1909 and are excluded from the city budget analysis (tables 3-6). Nineteen cities did not report complete paving data and are excluded from the paving analysis (tables 7 and 8). 
TABLE 2-REGRESSION ANALYSES OF MUNICIPAL WAGES OF UNSKILLED LABORERS

\begin{tabular}{|c|c|c|c|c|c|c|}
\hline \multirow{3}{*}{$\begin{array}{l}\text { Mean dep. var. } \\
\text { Std Dev. dep. var. } \\
\text { Adj. R } \\
\text { Root MSE } \\
\text { Variables }\end{array}$} & \multicolumn{2}{|c|}{$\begin{array}{c}(1) \\
\text { Unskilled wage } \\
\end{array}$} & \multicolumn{2}{|c|}{$\begin{array}{c}(2) \\
\text { Unskilled wage }\end{array}$} & \multicolumn{2}{|c|}{ Sample Statistics } \\
\hline & \multicolumn{2}{|c|}{$\begin{array}{l}0.617 \\
0.180 \\
0.430 \\
0.136\end{array}$} & \multicolumn{2}{|c|}{$\begin{array}{l}0.617 \\
0.180 \\
0.441 \\
0.135\end{array}$} & \multirow[b]{2}{*}{ Mean } & \multirow[b]{2}{*}{ Std Dev } \\
\hline & Coeff & Std Err & Coeff & Std Err & & \\
\hline In(population 1900) & .0247 & $(.017)$ & .016 & $(.020)$ & 11.37 & 0.902 \\
\hline $\ln ($ pop1910/pop1900) & -.061 & $(.085)$ & -.021 & $(-.083)$ & 0.366 & 0.250 \\
\hline $\begin{array}{l}\text { In(annual } \\
\text { wages/employee) in } \\
\text { bakeries }\end{array}$ & $.238 * *$ & $(.110)$ & .181 * & (.109) & 6.34 & 0.174 \\
\hline $\begin{array}{l}\% \text { employees of bakeries } \\
\text { who are adult males }\end{array}$ & -.248 & $(.157)$ & -.170 & (.162) & 0.802 & 0.117 \\
\hline machine dominated & 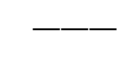 & $\longrightarrow$ & .082 ** & $(.040)$ & 0.232 & 0.423 \\
\hline $\begin{array}{l}\text { political structure not } \\
\text { categorized }\end{array}$ & - & 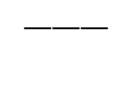 & .033 & $(.040)$ & 0.595 & 0.491 \\
\hline New England & .085 ** & $(.039)$ & .094 ** & $(.038)$ & $75 \mathrm{cit}$ & age obs \\
\hline East North Central & -.008 & $(.032)$ & -.007 & $(.031)$ & 74 cit & age obs \\
\hline West North Central & .005 & $(.053)$ & .012 & $(.053)$ & $39 \mathrm{cit}$ & age obs \\
\hline Mountain & $.242 * \star *$ & $(.052)$ & .226 *** & $(.047)$ & 8 city & ge obs \\
\hline Pacific & $.306 * * *$ & $(.074)$ & $.320 * * *$ & $(.074)$ & 25 cit & age obs \\
\hline South Atlantic & -.123 * & $(.067)$ & -.126 ** & $(.063)$ & $33 \mathrm{cit}$ & age obs \\
\hline East South Central & -.032 & $(.054)$ & -.045 & $(.056)$ & 24 cit & age obs \\
\hline West South Central & .091 & $(.062)$ & .098 & $(.065)$ & $15 \mathrm{cit}$ & age obs \\
\hline Refuse Collection & -.012 & $(.015)$ & -.012 & $(.015)$ & $75 \mathrm{cit}$ & age obs \\
\hline Street Cleaning & -.052 *** & $(.011)$ & -.051 *** & $(.010)$ & $100 \mathrm{ci}$ & vage obs \\
\hline Street Sprinkling & -.082 *** & $(.031)$ & $-.080 * * *$ & $(.031)$ & $13 \mathrm{cit}$ & age obs \\
\hline General Highway & -.032 *** & $(.009)$ & $-.033 * * *$ & $(.009)$ & $100 \mathrm{ci}$ & vage obs \\
\hline Constant & -.959 & (.601) & -.618 & $(.615)$ & & \\
\hline
\end{tabular}

Notes: Sample of 388 observed wage rates in 105 cities in 1909. See text and appendix B for explanation and sources of the city categories; see appendix A for other variables. Regression estimated using OLS and standard errors White-corrected for city fixed effects. Mid Atlantic, with 95 city-wage observations, is the omitted region; general sewer service, with 100 city-wage observations, is the omitted department. The regional classifications are the standard Census classifications. 
TABLE 3-AVERAGE MUNICIPAL SPENDING PER CAPITA, 1905-1909

\begin{tabular}{|c|c|c|c|c|c|c|c|c|}
\hline & \multicolumn{2}{|c|}{ All cities } & \multicolumn{2}{|c|}{ Machine cities } & \multicolumn{2}{|c|}{$\begin{array}{c}\text { Non-machine } \\
\text { cities }\end{array}$} & \multicolumn{2}{|c|}{ Not categorized } \\
\hline & Total & $\begin{array}{l}\text { Current } \\
\text { Infrast. } \\
\text { Interest }\end{array}$ & Total & $\begin{array}{l}\text { Current } \\
\text { Infrast. } \\
\text { Interest }\end{array}$ & Total & $\begin{array}{l}\text { Current } \\
\text { Infrast. } \\
\text { Interest }\end{array}$ & Total & $\begin{array}{l}\text { Current } \\
\text { Infrast. } \\
\text { Interest }\end{array}$ \\
\hline All Regions & 21.37 & $\begin{array}{r}12.38 \\
7.01 \\
1.79\end{array}$ & 25.23 & $\begin{array}{r}15.17 \\
7.75 \\
2.05\end{array}$ & 20.38 & $\begin{array}{r}10.80 \\
7.98 \\
1.42\end{array}$ & 20.15 & $\begin{array}{r}11.75 \\
6.43 \\
1.79\end{array}$ \\
\hline $\begin{array}{l}\text { New } \\
\text { England }\end{array}$ & 22.32 & $\begin{array}{r}14.87 \\
5.26 \\
2.08\end{array}$ & 30.90 & $\begin{array}{r}21.90 \\
5.46 \\
3.54\end{array}$ & 17.32 & $\begin{array}{r}11.85 \\
3.33 \\
1.79\end{array}$ & 21.56 & $\begin{array}{r}14.19 \\
5.36 \\
1.91\end{array}$ \\
\hline $\begin{array}{l}\text { Mid } \\
\text { Atlantic }\end{array}$ & 20.31 & $\begin{array}{r}12.46 \\
6.07 \\
1.60\end{array}$ & 25.91 & $\begin{array}{r}16.03 \\
7.61 \\
2.00\end{array}$ & 16.61 & $\begin{array}{r}10.31 \\
5.17 \\
1.00\end{array}$ & 18.43 & $\begin{array}{r}11.22 \\
5.53 \\
1.55\end{array}$ \\
\hline $\begin{array}{l}\text { East North } \\
\text { Central }\end{array}$ & 20.00 & $\begin{array}{r}11.51 \\
6.87 \\
1.37\end{array}$ & 24.11 & $\begin{array}{r}13.98 \\
8.01 \\
1.84\end{array}$ & 20.83 & $\begin{array}{r}12.40 \\
7.22 \\
1.11\end{array}$ & 17.45 & $\begin{array}{l}9.84 \\
6.12 \\
1.21\end{array}$ \\
\hline $\begin{array}{l}\text { West North } \\
\text { Central }\end{array}$ & 21.69 & $\begin{array}{r}12.18 \\
7.34 \\
1.69\end{array}$ & 24.77 & $\begin{array}{r}13.94 \\
8.59 \\
1.49\end{array}$ & 20.44 & $\begin{array}{r}12.37 \\
7.06 \\
.76\end{array}$ & 20.10 & $\begin{array}{r}11.08 \\
6.65 \\
1.99\end{array}$ \\
\hline Mountain & 28.21 & $\begin{array}{r}15.92 \\
10.32 \\
1.96\end{array}$ & 26.39 & $\begin{array}{r}17.56 \\
7.32 \\
1.50\end{array}$ & - & - & 30.03 & $\begin{array}{r}14.28 \\
13.33 \\
2.42\end{array}$ \\
\hline Pacific & 36.13 & $\begin{array}{r}12.96 \\
20.93 \\
2.22\end{array}$ & - & - & 45.60 & $\begin{array}{r}13.45 \\
29.84 \\
2.31\end{array}$ & 31.40 & $\begin{array}{r}12.71 \\
16.48 \\
2.17\end{array}$ \\
\hline $\begin{array}{l}\text { South } \\
\text { Atlantic }\end{array}$ & 18.88 & $\begin{array}{r}11.18 \\
5.47 \\
2.10\end{array}$ & 25.89 & $\begin{array}{r}14.32 \\
9.55 \\
2.02\end{array}$ & 15.49 & $\begin{array}{l}9.96 \\
4.25 \\
1.10\end{array}$ & 18.83 & $\begin{array}{r}11.04 \\
5.15 \\
2.52\end{array}$ \\
\hline $\begin{array}{l}\text { East South } \\
\text { Central }\end{array}$ & 16.56 & $\begin{array}{l}9.12 \\
5.08 \\
2.13\end{array}$ & 21.10 & $\begin{array}{r}11.80 \\
7.19 \\
2.12\end{array}$ & 10.28 & $\begin{array}{l}4.98 \\
3.70 \\
1.60\end{array}$ & 15.61 & $\begin{array}{l}8.71 \\
4.13 \\
2.31\end{array}$ \\
\hline $\begin{array}{l}\text { West } \\
\text { South } \\
\text { Central }\end{array}$ & 17.45 & $\begin{array}{l}9.59 \\
5.21 \\
2.28\end{array}$ & 22.90 & $\begin{array}{r}10.85 \\
9.10 \\
2.95\end{array}$ & 15.63 & $\begin{array}{l}9.16 \\
3.91 \\
2.05\end{array}$ & - & 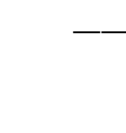 \\
\hline
\end{tabular}

Notes: 103 cities with population greater than 50,000 in 1910. Municipal spending averaged over 1905, 1907, and 1909. Infrast. is an abbreviation for infrastructure. The categories are not exhaustive; see text. See text and appendix B for explanation and sources of the city categories; see appendix A for other variables. The regional classifications are the standard Census classifications. 
TABLE 4-REGRESSION ANALYSIS OF PER CAPITA MUNICIPAL SPENDING

\begin{tabular}{|c|c|c|c|c|c|c|}
\hline \multirow{3}{*}{$\begin{array}{l}\text { Mean dep. var. } \\
\text { std dev. dep. var. } \\
\text { Adj. } \text { R }^{2} \\
\text { Root MSE } \\
\text { Variables }\end{array}$} & \multicolumn{2}{|c|}{$\begin{array}{c}\text { (1) } \\
\text { Per capita budget } \\
\end{array}$} & \multicolumn{2}{|c|}{$\begin{array}{c}\text { (2) } \\
\text { Per capita budget }\end{array}$} & \multicolumn{2}{|c|}{$\begin{array}{c}\text { Sample Statistics } \\
103 \text { cities }\end{array}$} \\
\hline & \multicolumn{2}{|c|}{$\begin{array}{l}3.01 \\
0.320 \\
0.521 \\
0.221\end{array}$} & \multicolumn{2}{|c|}{$\begin{array}{c}3.01 \\
0.320 \\
0.538 \\
0.217\end{array}$} & \multirow[b]{2}{*}{ Mean } & \multirow[b]{2}{*}{ Std Dev } \\
\hline & Coeff & Std Err & Coeff & Std Err & & \\
\hline In(population 1900) & $.198 * \star \star$ & $(.029)$ & $.177^{\star * \star}$ & $(.034)$ & 11.37 & 0.907 \\
\hline In(pop1910/pop1900) & .049 & $(.163)$ & .106 & (.163) & 0.358 & 0.242 \\
\hline In(land/pop) in 1900 & .106 ** & $(.046)$ & .112 ** & $(.045)$ & -9.21 & 0.740 \\
\hline In(land1909/land1900) & .217 ** & $(.090)$ & .212 ** & $(.089)$ & 0.174 & 0.305 \\
\hline $\begin{array}{l}\% \text { pop age } 10+\text { employed in } \\
\text { mfg }\end{array}$ & $-.974 * * *$ & $(.360)$ & $-.941 * \star *$ & $(.355)$ & 0.172 & 0.096 \\
\hline$\%$ foreign born $^{a}$ & -.032 & (.214) & -.006 & (.211) & 0.343 & 0.151 \\
\hline $\begin{array}{l}\% \text { native born with foreign }^{\text {parents }^{\mathrm{a}}}\end{array}$ & .360 & $(.396)$ & .210 & (.396) & 0.236 & 0.076 \\
\hline machine dominated & - & 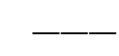 & $.183 * *$ & $(.082)$ & & \\
\hline $\begin{array}{l}\text { political structure not } \\
\text { categorized }\end{array}$ & 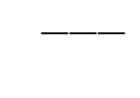 & 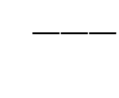 & .074 & $(.068)$ & & \\
\hline New England & $.172 * \star$ & $(.081)$ & $.169 * *$ & (.081) & & \\
\hline East North Central & -.078 & $(.069)$ & -.073 & (.068) & & \\
\hline West North Central & -.133 & $(.104)$ & -.137 & (.103) & & \\
\hline Mountain & .086 & $(.185)$ & .033 & (.184) & & \\
\hline Pacific & $.334 * *$ & $(.144)$ & $.324 * *$ & (.142) & & \\
\hline South Atlantic & -.080 & $(.106)$ & -.064 & (.104) & & \\
\hline East South Central & $-.306 * * *$ & $(.114)$ & $-.313 * * *$ & (.113) & & \\
\hline West South Central & $-.394 * * *$ & (.144) & -.363 ** & (.149) & & \\
\hline Constant & $1.78 * * \star$ & (.504) & $2.00 * \star \star$ & (.563) & & \\
\hline
\end{tabular}

a among white males age 21+

Notes: 103 cities with population greater than 50,000 in 1910. All spending is expressed as the log of the average of per capita spending in 1905, 1907, and 1909. The Mid Atlantic, with 28 cities, is the omitted region. See text and appendix B for political categories and appendix A for sources of other variables. The symbols *, **, and ${ }^{* *}$ indicate that the coefficient is significantly different from zero at at least the $10 \%, 5 \%$, and $1 \%$ levels respectively. Land area is expressed as the log of per capita area, measured in thousands of acres. The regional classifications are the standard Census classifications. 
TABLE 5-REGRESSION ANALYSIS OF AVERAGE PER CAPITA CURRENT EXPENSES BY DEPARTMENT: 1905 AND 1907 POLITICAL STRUCTURE DUMMIES NOT INCLUDED

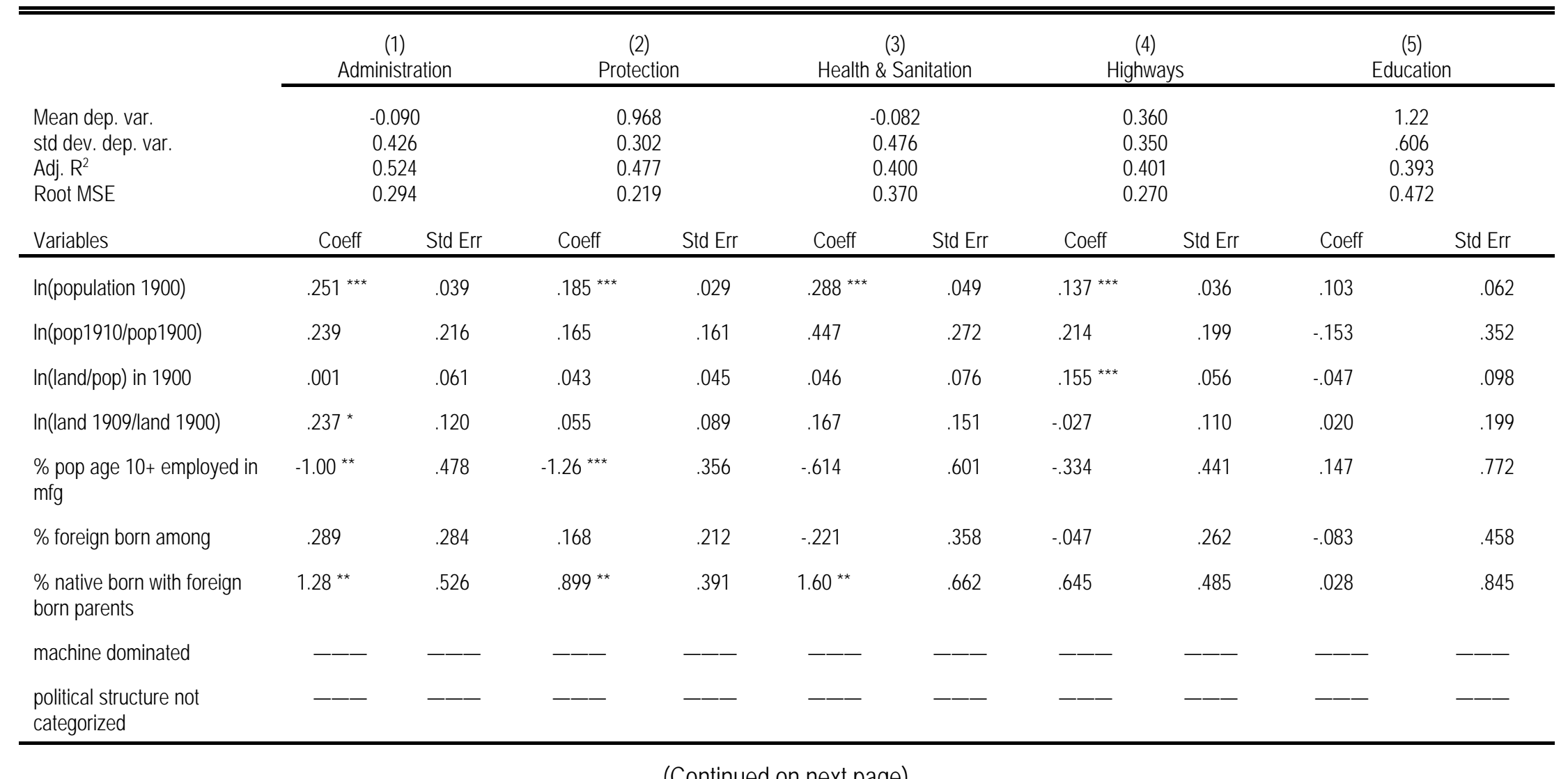

(Continued on next page) 
TABLE 5-REGRESSION ANALYSIS OF AVERAGE PER CAPITA CURRENT EXPENSES BY DEPARTMENT (CONTINUED)

\begin{tabular}{|c|c|c|c|c|c|c|c|c|c|c|}
\hline \multirow[b]{2}{*}{ Variables } & \multicolumn{2}{|c|}{$\begin{array}{c}(1) \\
\text { Administration } \\
\end{array}$} & \multicolumn{2}{|c|}{$\begin{array}{c}(2) \\
\text { Protection } \\
\end{array}$} & \multicolumn{2}{|c|}{$\begin{array}{c}\text { (3) } \\
\text { Health \& Sanitation }\end{array}$} & \multicolumn{2}{|c|}{$\begin{array}{c}\text { (4) } \\
\text { Highways }\end{array}$} & \multicolumn{2}{|c|}{$\begin{array}{c}(5) \\
\text { Education }\end{array}$} \\
\hline & Coeff & Std Err & Coeff & Std Err & Coeff & Std Err & Coeff & Std Err & Coeff & Std Err \\
\hline New England & .266 ** & .108 & $.304 * \star \star$ & .080 & $.449 * * \star$ & .136 & $.482 * * \star$ & .099 & .175 & .173 \\
\hline East North Central & -.191 ** & .092 & -.011 & .068 & -.163 & .116 & -.118 & .085 & .029 & .148 \\
\hline West North Central & -.210 & .138 & -.098 & .103 & -.341 * & .174 & .036 & .128 & .066 & .223 \\
\hline Mountain & $.759 * * \star$ & .246 & -.323 * & .183 & .027 & .309 & .021 & .226 & .536 & .395 \\
\hline Pacific & -.137 & .192 & -.211 & .143 & -.278 & .241 & -.092 & .177 & .353 & .308 \\
\hline South Atlantic & .097 & .140 & .175 * & .104 & $.556 * * \star$ & .177 & .127 & .129 & $-1.35 * \star *$ & .225 \\
\hline East South Central & $-.469 * \star *$ & .151 & -.162 & .112 & -.112 & .190 & -.093 & .139 & -.505 * & .255 \\
\hline West South Central & -.156 & .191 & -.338 ** & .142 & -.117 & .240 & -.108 & .176 & -.283 & .307 \\
\hline Constant & -3.26 *** & .669 & -.882 * & .498 & -3.36 *** & .843 & .020 & .617 & -.269 & 1.09 \\
\hline
\end{tabular}

a among white males 21+

Notes: 103 cities with population greater than 50,000 in 1900. All spending is expressed as the log of the average of per capita spending by department in 1905 and 1907 . The Mid Atlantic, with 28 cities, is the omitted region. See text and appendix B for political categories and appendix A for other variables. The symbols *, ${ }^{*}$, and ${ }^{* \star *}$ indicate that the coefficient is significantly different from zero at at least the $10 \%, 5 \%$, and $1 \%$ levels respectively. Land area is expressed as the log of per capita area, measured in thousands of acres. Sample statistics presented in table 4 . The regional classifications are the standard Census classifications. 
TABLE 6-REGRESSION ANALYSIS OF AVERAGE PER CAPITA CURRENT EXPENSES BY DEPARTMENT

POLITICAL STRUCTURE DUMMIES INCLUDED

\begin{tabular}{|c|c|c|c|c|c|c|c|c|c|c|}
\hline \multirow{3}{*}{$\begin{array}{l}\text { Mean dep. var. } \\
\text { std dev. dep. var. } \\
\text { Adj. } \text { R }^{2} \\
\text { Root MSE } \\
\text { Variables }\end{array}$} & \multicolumn{2}{|c|}{$\begin{array}{c}(1) \\
\text { Administration }\end{array}$} & \multicolumn{2}{|c|}{$\begin{array}{c}(2) \\
\text { Protection }\end{array}$} & \multicolumn{2}{|c|}{$\begin{array}{c}\text { (3) } \\
\text { Health \& Sanit }\end{array}$} & \multicolumn{2}{|c|}{$\begin{array}{c}\text { (4) } \\
\text { Highways }\end{array}$} & \multicolumn{2}{|c|}{$\begin{array}{c}(5) \\
\text { Education }\end{array}$} \\
\hline & \multicolumn{2}{|c|}{$\begin{array}{c}-0.090 \\
0.426 \\
0.644 \\
0.278\end{array}$} & \multicolumn{2}{|c|}{$\begin{array}{l}0.968 \\
0.302 \\
0.498 \\
0.214\end{array}$} & \multicolumn{2}{|c|}{$\begin{array}{c}-0.082 \\
0.476 \\
0.397 \\
0.370\end{array}$} & \multicolumn{2}{|c|}{$\begin{array}{l}.360 \\
.350 \\
.389 \\
.274\end{array}$} & \multicolumn{2}{|c|}{$\begin{array}{l}1.22 \\
.606 \\
.390 \\
.473\end{array}$} \\
\hline & Coeff & Std Err & Coeff & Std Err & Coeff & Std Err & Coeff & Std Err & Coeff & Std Err \\
\hline In(population 1900) & $.194 * \star \star$ & .043 & $.158 * \star \star$ & .033 & $.274 * \star *$ & .057 & $.128^{* * *}$ & .042 & .082 & .073 \\
\hline In(pop1910/pop1900) & .329 & .208 & .217 & .160 & .517 * & .276 & .221 & .205 & -.226 & .359 \\
\hline In(land/pop) in 1900 & .016 & .058 & .050 & .044 & .050 & .077 & .157 *** & .057 & -.042 & .099 \\
\hline In(land 1909/land 1900) & $.231 * *$ & .114 & .051 & .087 & .161 & .151 & -.027 & .112 & .028 & .199 \\
\hline $\begin{array}{l}\text { \% pop age } 10+\text { employed in } \\
\text { mfg }\end{array}$ & $-.959 * *$ & .454 & $-1.23 * \star *$ & .349 & -.567 & .603 & -.332 & .446 & .083 & .776 \\
\hline$\%$ foreign born & .328 & .270 & .192 & .208 & -.188 & .359 & -.044 & .266 & -.122 & .461 \\
\hline $\begin{array}{l}\% \text { native born with foreign } \\
\text { born parents }\end{array}$ & 1.03 ** & .507 & .754 * & .390 & 1.43 ** & .673 & .619 & .498 & .180 & .862 \\
\hline machine dominated & $.339 * * \star$ & .105 & .186 ** & .080 & .198 & .139 & .039 & .103 & -.130 & .178 \\
\hline $\begin{array}{l}\text { political structure not } \\
\text { categorized }\end{array}$ & .078 & .087 & .055 & .067 & .112 & .115 & -.001 & .085 & -182 & .147 \\
\hline
\end{tabular}

(Continued on next page) 
TABLE 6 (CONT.)

REGRESSION ANALYSIS OF AVERAGE PER CAPITA CURRENT EXPENSES BY DEPARTMENT

\begin{tabular}{|c|c|c|c|c|c|c|c|c|c|c|}
\hline \multirow[b]{2}{*}{ Variables } & \multicolumn{2}{|c|}{$\begin{array}{c}(1) \\
\text { Administration } \\
\end{array}$} & \multicolumn{2}{|c|}{$\begin{array}{c}(2) \\
\text { Protection } \\
\end{array}$} & \multicolumn{2}{|c|}{$\begin{array}{c}(3) \\
\text { Health \& Sanit } \\
\end{array}$} & \multicolumn{2}{|c|}{$\begin{array}{c}(4) \\
\text { Highways } \\
\end{array}$} & \multicolumn{2}{|c|}{$\begin{array}{c}(5) \\
\text { Education } \\
\end{array}$} \\
\hline & Coeff & Std Err & Coeff & Std Err & Coeff & Std Err & Coeff & Std Err & Coeff & Std Err \\
\hline New England & $.272^{* \star \star}$ & .103 & $.305 * \star \star$ & .079 & $.439 * \star \star$ & .137 & $.485 * \star \star$ & .101 & .203 & .176 \\
\hline East North Central & $-.190 * *$ & .088 & -.009 & .067 & -.155 & .116 & -.119 & .086 & .013 & .149 \\
\hline West North Central & $-.221 *$ & .131 & -.104 & .101 & -.344 * & .174 & .034 & .129 & .063 & .224 \\
\hline Mountain & $.648 * * *$ & .235 & $-.382 * *$ & .181 & -.023 & .312 & .006 & .231 & .543 & .400 \\
\hline Pacific & -.154 & .182 & -.221 & .140 & -.289 & .241 & .094 & .179 & .361 & .309 \\
\hline South Atlantic & .124 & .133 & .191 * & .102 & $.575^{* * \star}$ & .177 & .130 & .131 & $-1.36 * * \star$ & .227 \\
\hline East South Central & 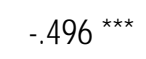 & .144 & -.173 & .111 & -.112 & .191 & -.099 & .142 & -.531 ** & .258 \\
\hline West South Central & -.144 & .190 & -.322 ** & .146 & -.060 & .252 & -.114 & .187 & -.403 & .324 \\
\hline Constant & $-2.60 * * *$ & .720 & -.574 & .554 & $-3.27 * \star *$ & .956 & .140 & .708 & .176 & 1.23 \\
\hline
\end{tabular}

a among white males 21+

Notes: 103 cities with population greater than 50,000 in 1900. All spending is expressed as the log of the average of per capita spending by department in 1905 and 1907 . The Mid Atlantic, with 28 cities, is the omitted region. See text and appendix B for city political categories and appendix A for other variables. The symbols ${ }^{*}$, ${ }^{*}$, and ${ }^{* \star *}$ indicate that the coefficient is significantly different from zero at at least the $10 \%, 5 \%$, and $1 \%$ levels respectively. Land area is expressed as the log of per capita area, measured in thousands of acres. Sample statistics presented in table 4. The regional classifications are the standard Census classifications 
TABLE 7-REGRESSION ANALYSIS OF AVERAGE PROPORTION OF STREETS PAVED WITH DURABLE PAVING, 1903-1909

POLITICAL STRUCTURE DUMMIES NOT INCLUDED

\begin{tabular}{|c|c|c|c|c|c|c|c|c|}
\hline \multirow[b]{2}{*}{$\begin{array}{l}\text { Observations } \\
\text { Mean dep. var. } \\
\text { Std dev dep. var. } \\
\text { Adj. R } \\
\text { Root MSE }\end{array}$} & \multicolumn{2}{|c|}{$\begin{array}{c}(1) \\
\text { All cities and regions }\end{array}$} & \multicolumn{2}{|c|}{$\begin{array}{c}(2) \\
\text { Northeast cities }\end{array}$} & \multicolumn{2}{|c|}{$\begin{array}{c}(3) \\
\text { Medium sized cities }\end{array}$} & \multicolumn{2}{|c|}{$\begin{array}{c}(4) \\
\text { Medium sized Northeast } \\
\text { cities }\end{array}$} \\
\hline & $\begin{array}{l}87 \\
0.235 \\
0.164 \\
0.433 \\
0.123\end{array}$ & & $\begin{array}{l}51 \\
0.289 \\
0.147 \\
0.322 \\
0.121\end{array}$ & & $\begin{array}{l}75 \\
0.209 \\
0.145 \\
0.372 \\
0.115\end{array}$ & & $\begin{array}{l}42 \\
0.267 \\
0.143 \\
0.337 \\
0.116\end{array}$ & \\
\hline Variables & Coeff & Std Err & Coeff & Std Err & Coeff & Std Err & Coeff & Std Err \\
\hline In(population 1900) & $.154^{\star \star \star}$ & .024 & $.126^{\star * *}$ & .034 & $.134^{* * *}$ & .034 & $.136^{* * *}$ & .047 \\
\hline In(pop 1910/ pop 1900) & -.003 & .071 & -.003 & .158 & .009 & .070 & .046 & .162 \\
\hline In(land in 1909) & $.110^{\star * *}$ & .022 & $-.093^{* * *}$ & .032 & $-.104^{* * *}$ & .022 & $-.093^{* * *}$ & .032 \\
\hline $\begin{array}{l}\text { In(annual wages of bakery } \\
\text { employees) }\end{array}$ & -.007 & .092 & .238 & .166 & .008 & .090 & .245 & .173 \\
\hline$\%$ foreign born & -.173 & .108 & -.191 & .155 & -.150 & .108 & -.219 & .161 \\
\hline $\begin{array}{l}\% \text { native born with foreign born } \\
\text { parents }\end{array}$ & .317 & .206 & .419 & .276 & $.402 *$ & .221 & $.600 *$ & .308 \\
\hline constant & $-1.23^{* *}$ & .589 & $-2.50 * *$ & .989 & $-1.16^{*}$ & .595 & $-2.71 * *$ & 1.03 \\
\hline
\end{tabular}

Notes: All cities indicates all cities with population above 50,000 in 1907 for which paving data is available. Medium sized cities indicates cities with population between 50,000 and 300,000 in 1907 for which paving data is available. Land Area in 1000s of acres. 
TABLE 8-REGRESSION ANALYSIS OF AVERAGE PROPORTION OF STREETS PAVED WITH DURABLE PAVING, 1903-1909

POLITICAL STRUCTURE DUMMIES INCLUDED

\begin{tabular}{|c|c|c|c|c|c|c|c|c|}
\hline \multirow[b]{2}{*}{$\begin{array}{l}\text { Observations } \\
\text { Mean dep. var. } \\
\text { Std dev dep. var. } \\
\text { Adj. R }{ }^{2} \\
\text { Root MSE }\end{array}$} & \multicolumn{2}{|c|}{$\begin{array}{c}(1) \\
\text { All cities and regions }\end{array}$} & \multicolumn{2}{|c|}{$\begin{array}{c}(2) \\
\text { Northeast cities }\end{array}$} & \multicolumn{2}{|c|}{$\begin{array}{c}(3) \\
\text { Medium sized cities }\end{array}$} & \multicolumn{2}{|c|}{$\begin{array}{c}(4) \\
\text { Medium Northeast cities }\end{array}$} \\
\hline & $\begin{array}{l}87 \\
0.235 \\
0.164 \\
0.433 \\
0.123\end{array}$ & & $\begin{array}{l}51 \\
0.289 \\
0.147 \\
0.322 \\
0.121\end{array}$ & & $\begin{array}{l}75 \\
0.209 \\
0.145 \\
0.372 \\
0.115\end{array}$ & & $\begin{array}{l}42 \\
0.267 \\
0.143 \\
0.337 \\
0.116\end{array}$ & \\
\hline Variables & Coeff & Std Err & Coeff & Std Err & Coeff & Std Err & Coeff & Std Err \\
\hline In(population 1900) & $.116^{\star * *}$ & .026 & $.094^{* * *}$ & .034 & $.089 * *$ & .035 & $.108^{* *}$ & .046 \\
\hline In(рор 1910/ рор 1900) & -.022 & .071 & .031 & .150 & -.025 & .069 & .089 & .152 \\
\hline In(area in 1909) & $-.105^{\star * \star}$ & .021 & $-.089 * * *$ & .030 & $-.097^{\star * *}$ & .021 & $-.094^{* * *}$ & .031 \\
\hline $\begin{array}{l}\text { In(annual wages of bakery } \\
\text { employees) }\end{array}$ & .019 & .090 & .231 & .161 & .037 & .087 & .217 & .163 \\
\hline$\%$ foreign born & -.142 & .105 & -.130 & .148 & -.127 & .102 & -.136 & .155 \\
\hline$\%$ native w/ foreign parents & .219 & .203 & .291 & .267 & .337 & .216 & .503 & .298 \\
\hline machine dominated & $.112^{\star * \star}$ & .040 & $.113^{* *}$ & .046 & $.110^{* * *}$ & .038 & $.106^{* *}$ & .045 \\
\hline $\begin{array}{l}\text { Political structure categorized: } \\
\text { NO machine present }\end{array}$ & .067 & .041 & $.104^{*}$ & .056 & $.074^{*}$ & .042 & $.108^{*}$ & .064 \\
\hline constant & -.999 & .583 & $-2.15^{\star \star}$ & .984 & -.867 & .575 & -2.28 & .987 \\
\hline
\end{tabular}


The sample of 103 cities analyzed is fundamentally the list of all cities with population greater than 50,000 in the 1910 Census of Population. Both samples omit Washington, DC and San Francisco. San Francisco is dropped because of the impact of the earthquake in 1906 on observed city characteristics, both population and finances.

\begin{tabular}{|c|c|c|}
\hline Variable & Source & Notes \\
\hline machine dominated & See text and appendix B. & $\begin{array}{l}\text { coded } 1 \text { if evidence of significant machine politics, } 0 \\
\text { otherwise. }\end{array}$ \\
\hline $\begin{array}{l}\text { political structure not } \\
\text { categorized }\end{array}$ & See text. & $\begin{array}{l}\text { coded } 1 \text { if political history not discovered, } 0 \text { if city is } \\
\text { known to be machine dominated or non-machine. }\end{array}$ \\
\hline $\begin{array}{l}\text { Political structure } \\
\text { categorized: } \\
\text { NO machine present }\end{array}$ & See text and appendix B. & $\begin{array}{l}\text { coded } 1 \text { if a political history was found and there was } \\
\text { no evidence of machine domination. }\end{array}$ \\
\hline City population in 1900 & 12th Census: 1900 vol. 1 & $\begin{array}{l}\text { Log of the population in } 1900 \text { is used in the } \\
\text { regression analysis. }\end{array}$ \\
\hline City population in 1910 & 13th Census: 1910 vol. 1 & $\begin{array}{l}\text { Log difference of population in } 1910 \text { and } 1900 \text { is } \\
\text { used in the regression analysis. }\end{array}$ \\
\hline land area in 1900 & Statistics of Cities: 1905 & $\begin{array}{l}\text { The log of the land area in thousands of acres per } \\
\text { capita is used in the regression analysis. }\end{array}$ \\
\hline land area in 1909 & $\begin{array}{l}\text { Financial Statistics of Cities: } \\
1909\end{array}$ & $\begin{array}{l}\text { The log difference of land area in } 1909 \text { and in } 1900 \\
\text { is used in the regression analysis. }\end{array}$ \\
\hline $\begin{array}{l}\% \text { population aged } 10 \text { and } \\
\text { older employed in } \\
\text { manufacturing in } 1910\end{array}$ & 13th Census: 1910 vol. 4 & $\begin{array}{l}\text { Tables III and IV list occupations of population by } \\
\text { city. Robert Whaples generously provided the data } \\
\text { in machine readable format. }\end{array}$ \\
\hline $\begin{array}{l}\% \text { foreign born among } \\
\text { white males } 21+\end{array}$ & 12th Census: 1900 vol.1 & $\begin{array}{l}\text { Proportion of foreign born among white males age } \\
21 \text { or older. }\end{array}$ \\
\hline $\begin{array}{l}\% \text { native born with foreign } \\
\text { parents among white males } \\
21+\end{array}$ & 12th Census: 1900 vol.1 & $\begin{array}{l}\text { Proportion of native born with foreign parents among } \\
\text { white males age } 21 \text { or older. }\end{array}$ \\
\hline $\begin{array}{l}\text { Annual wages of bakery } \\
\text { employees }\end{array}$ & 13th Census: 1910 vol.9 & $\begin{array}{l}\text { Total costs and average employment by industry are } \\
\text { reported for cities with populations greater than } \\
50,000 \text {. Tables in source are arranged by state. The } \\
\text { log of the average annual wages per employee is } \\
\text { used in the regression analysis. }\end{array}$ \\
\hline $\begin{array}{l}\% \text { employees of bakeries } \\
\text { who are adult males. }\end{array}$ & 13th Census: 1910 vol.9 & See above notes. \\
\hline
\end{tabular}




\begin{tabular}{|c|c|c|}
\hline Variable & Source & Notes \\
\hline Region & $\begin{array}{l}\text { The } 9 \text { standard Census } \\
\text { classifications. }\end{array}$ & $\begin{array}{l}\text { Cities are found in the following states: } \\
\text { New England: CT, MA, ME, NH, RI } \\
\text { Mid Atlantic: NJ, NY, PA } \\
\text { East North Central: IL, IN, MI, OH, WI } \\
\text { West North Central: IA, KS, MN, MO, NE } \\
\text { Mountain: CO, MT, UT } \\
\text { Pacific: CA, OR, WA } \\
\text { South Atlantic: DE, FL, GA, MD, SC, VA, WV } \\
\text { East South Central: AL, KY, TN } \\
\text { West South Central: AR, LA, OK, TX. }\end{array}$ \\
\hline $\begin{array}{l}\text { Daily municipal wages of } \\
\text { unskilled laborers. }\end{array}$ & $\begin{array}{l}\text { General Statistics of Cities: } \\
1909\end{array}$ & $\begin{array}{l}\text { Wages by department, as reported by the city to the } \\
\text { Census Bureau. }\end{array}$ \\
\hline $\begin{array}{l}\text { Per capita average } \\
\text { municipal budget }\end{array}$ & $\begin{array}{l}\text { Statistics of Cities: } 1905 \\
\text { Statistics of Cities: } 1907 \\
\text { Financial Statistics of Cities: } \\
1909\end{array}$ & $\begin{array}{l}\text { Log of the average of 1905, } 1907 \text { and } 1909 \text { per } \\
\text { capita total corporate payments is used in the } \\
\text { regression analysis. }\end{array}$ \\
\hline $\begin{array}{l}\text { Per capita average } \\
\text { municipal administration } \\
\text { expenses }\end{array}$ & $\begin{array}{l}\text { Statistics of Cities: } 1905 \\
\text { Statistics of Cities: } 1907\end{array}$ & $\begin{array}{l}\text { Log of the average of } 1905 \text { and } 1907 \text { per capita } \\
\text { current expenses for general administration is used } \\
\text { in the regression analysis. }\end{array}$ \\
\hline $\begin{array}{l}\text { Per capita average } \\
\text { municipal protection } \\
\text { expenses }\end{array}$ & $\begin{array}{l}\text { Statistics of Cities: } 1905 \\
\text { Statistics of Cities: } 1907\end{array}$ & $\begin{array}{l}\text { Log of the average of } 1905 \text { and } 1907 \text { per capita } \\
\text { current expenses for police, fire, and other protection } \\
\text { of life and property is used in the regression } \\
\text { analysis. }\end{array}$ \\
\hline $\begin{array}{l}\text { Per capita average } \\
\text { municipal health and } \\
\text { sanitation expenses }\end{array}$ & $\begin{array}{l}\text { Statistics of Cities: } 1905 \\
\text { Statistics of Cities: } 1907\end{array}$ & $\begin{array}{l}\text { Log of the average of } 1905 \text { and } 1907 \text { per capita } \\
\text { current expenses for health and sanitation is used in } \\
\text { the regression analysis. }\end{array}$ \\
\hline $\begin{array}{l}\text { Per capita average } \\
\text { municipal highway } \\
\text { expenses }\end{array}$ & $\begin{array}{l}\text { Statistics of Cities: } 1905 \\
\text { Statistics of Cities: } 1907\end{array}$ & $\begin{array}{l}\text { Log of the average of } 1905 \text { and } 1907 \text { per capita } \\
\text { current expenses for streets, sidewalks, bridges, etc. } \\
\text { is used in the regression analysis. }\end{array}$ \\
\hline $\begin{array}{l}\text { Per capita average } \\
\text { municipal education } \\
\text { expenses }\end{array}$ & $\begin{array}{l}\text { Statistics of Cities: } 1905 \\
\text { Statistics of Cities: } 1907\end{array}$ & $\begin{array}{l}\text { Log of the average of } 1905 \text { and } 1907 \text { per capita } \\
\text { current expenses for education is used in the } \\
\text { regression analysis. }\end{array}$ \\
\hline $\begin{array}{l}\text { Proportion of streets paved } \\
\text { with durable paving in } \\
1909 .\end{array}$ & $\begin{array}{l}\text { General Statistics of Cities: } \\
1909\end{array}$ & $\begin{array}{l}\text { Paved streets are measured by the mile. As wider } \\
\text { streets were more likely to be paved, the proportion } \\
\text { of street area paved is probably somewhat higher. }\end{array}$ \\
\hline
\end{tabular}


APPENDIX B: SHORT POLITICAL HISTORIES OF MACHINE AND NON-MACHINE DOMINATED CITIES

TABLE B-1-NON-MACHINE CITIES

\begin{tabular}{|c|c|c|}
\hline City & Political History & Source \\
\hline Atlanta GA & $\begin{array}{l}\text { Municipal politics overshadowed by state politics. } \\
\text { No home rule. No machine }\end{array}$ & $\begin{array}{l}\text { Buenker and Kantowicz } \\
1988\end{array}$ \\
\hline Birmingham AL & $\begin{array}{l}\text { Never a machine city. Political competition } \\
\text { between largely German-American ethnics and } \\
\text { native whites. }\end{array}$ & Harris 1977 \\
\hline Buffalo NY & $\begin{array}{l}\text { Politics dominated by German Americans. } \\
\text { Elections fought on issues, not by organizations. }\end{array}$ & Goldman 1983 \\
\hline Butte MT & Politics dominated by Anaconda Copper. & Gimpel 1994 \\
\hline Dallas TX & $\begin{array}{l}\text { Adopted city manager system in } 1907 \text {. No } \\
\text { machine politics evident. }\end{array}$ & Stone, Price and Stone 1940 \\
\hline Des Moines IA & $\begin{array}{l}\text { One of the first cities to adopt the Commission } \\
\text { form of Government, in 1907. Not a machine } \\
\text { before reform or after. }\end{array}$ & Rice 1977 \\
\hline Detroit MI & $\begin{array}{l}\text { One of the first Progressive mayors, Pingree, in } \\
\text { the 1890s. Business reform movement led by } \\
\text { Leland, President of Cadillac, c. } 1910 .\end{array}$ & $\begin{array}{l}\text { Elenbaas } 1974 \\
\text { Holli and Jones } 1981\end{array}$ \\
\hline Fall River MA & $\begin{array}{l}\text { Irish Democrats fail to organize. Republicans, } \\
\text { with French Canadian, English, and native born } \\
\text { Protestant support, dominated politics; distributed } \\
\text { little patronage to these groups, not a machine. }\end{array}$ & Silvia 1973 \\
\hline Galveston TX & $\begin{array}{l}\text { Commission government form invented in early } \\
1900 \text { s, following physical destruction of city in a } \\
\text { hurricane. Never a machine. }\end{array}$ & Rice 1977 \\
\hline Harrisburg PA & $\begin{array}{l}\text { State capital. Politics dominated by state politics } \\
\text { and local businessmen. }\end{array}$ & Eggert 1993 \\
\hline Houston TX & $\begin{array}{l}\text { Active reform politics. One of the first cities to } \\
\text { adopt the Commission form of government. }\end{array}$ & Rice 1977 \\
\hline Indianapolis IN & $\begin{array}{l}\text { Local political competition lively and corruption is } \\
\text { an issue. Mayor Bell indicted for voting } \\
\text { irregularities, } 1915 .\end{array}$ & $\begin{array}{l}\text { Bodenhamer and Barrows } \\
1994\end{array}$ \\
\hline
\end{tabular}


TABLE B-1-Non-Machine Cities

\begin{tabular}{|c|c|c|}
\hline City & Political History & Source \\
\hline Los Angeles CA & $\begin{array}{l}\text { Active reform politics. Many popular structural } \\
\text { reforms passed. }\end{array}$ & $\begin{array}{l}\text { Holli and Jones } 1981 \\
\text { Buenker and Kantowicz } \\
1988\end{array}$ \\
\hline Milwaukee WI & $\begin{array}{l}\text { In } 1910 \text { Milwaukee elects a Socialist mayor who } \\
\text { remains in office through end of period. }\end{array}$ & Booth 1985 \\
\hline Passaic NJ & $\begin{array}{l}\text { Business elites defeat emerging Irish machine in } \\
\text { the 1910s. }\end{array}$ & Ebner 1972 \\
\hline San Antonio TX & $\begin{array}{l}\text { Machine politics in } 1880 \text { s and } 1890 \text { s, but } \\
\text { machine defeated by } 1900-1920 \text {. German and } \\
\text { Mexican American coalition had succumbed to } \\
\text { influx of native white voters. The boss, Bryan } \\
\text { Callaghan, remains an important political figure, } \\
\text { but without a machine. }\end{array}$ & Baum and Miller 1993 \\
\hline San Francisco CA & $\begin{array}{l}\text { Machine politics in } 1880 \text { s and } 1890 \text { s, but } \\
\text { machine falls after death of the "blind boss" } \\
\text { Buckley. Abraham Ruef, although corrupt, fails to } \\
\text { organize a machine. His regime falls after only a } \\
\text { few years. }\end{array}$ & $\begin{array}{l}\text { Bean } 1968 \\
\text { Buenker and Kantowicz } \\
1988\end{array}$ \\
\hline Seattle WA & $\begin{array}{l}\text { Borderline case. Hiram Gill has boss-like } \\
\text { characteristics, but fails to build lasting party } \\
\text { hierarchy. Union politics important. }\end{array}$ & $\begin{array}{l}\text { Berner } 1991 \\
\text { Blackford } 1968\end{array}$ \\
\hline Toledo $\mathrm{OH}$ & $\begin{array}{l}\text { Toledo's mayor in the 1890s, Samuel "Golden } \\
\text { Rule" Johnson, left a strong tradition of socially } \\
\text { responsible reform government. }\end{array}$ & Stinchcombe 1968 \\
\hline Wilmington DE & $\begin{array}{l}\text { Government dominated by local business } \\
\text { leaders. DuPont headquarters established in } \\
\text { Wilmington during the period. }\end{array}$ & Hoffecker 1983 \\
\hline
\end{tabular}

Notes: All references refer to sources listed in the References. 
TABLE B-2-MACHINE CITIES

\begin{tabular}{|c|c|c|}
\hline City & Political History & Source \\
\hline Albany NY & $\begin{array}{l}\text { Controlled by a Republican machine } 1900-1920 \text {. In } \\
1920 \text { the Democratic O'Connell machine took over, } \\
\text { controlled Albany until the 1980s. }\end{array}$ & Robinson 1977 \\
\hline Baltimore MD & $\begin{array}{l}\text { Democratic machine. Boss Rasin died in } 1911 . \\
\text { "Sonny" Mahon succeeded Rasin. Machine not } \\
\text { completely dominant; neither Rasin nor Mahon were } \\
\text { the only political forces in the city. }\end{array}$ & $\begin{array}{l}\text { Boulay and DiGaetano } \\
1985 \\
\text { Crooks } 1968\end{array}$ \\
\hline Boston MA & $\begin{array}{l}\text { 1900-1910 dominated by the rival machine } \\
\text { organizations of John "Honey Fitz" Fitzgerald and } \\
\text { Martin "Mahatma" Lomasney. 1910-1920 dominated } \\
\text { by machine rivalry between "Honey Fitz" and James } \\
\text { Curley. }\end{array}$ & Holli and Jones 1981 \\
\hline Chicago IL & $\begin{array}{l}\text { Machine present but formed alliances, such as with } \\
\text { reform mayor Carter Harrison II. The monolithic } \\
\text { Democratic Chicago machine was established by } \\
\text { Czermack c.1930. }\end{array}$ & Forthal 1946 \\
\hline Cincinnati OH & $\begin{array}{l}\text { Republican machine controls c.1900-1925. Survived } \\
\text { indictment of boss George B. Cox in 1910. Finally } \\
\text { defeated in elections in 1925. Similar to Denver and } \\
\text { Grand Rapids, machine adopted Progressive } \\
\text { measures to garner political support. }\end{array}$ & $\begin{array}{l}\text { Buenker and Kantowicz } \\
1988\end{array}$ \\
\hline Cleveland $\mathrm{OH}$ & $\begin{array}{l}\text { Home of famous reform mayor, Democrat Tom } \\
\text { Johnson, 1901-1909, but Republican machine, } \\
\text { headed by Maurice Maschke, controlled city council } \\
\text { c.1910-1919, with German-American support. }\end{array}$ & $\begin{array}{l}\text { Holli and Jones } 1981 \\
\text { DiGaetano } 1991\end{array}$ \\
\hline Dayton $\mathrm{OH}$ & $\begin{array}{l}\text { Republican Boss "Doc" Lowes and Democratic Boss } \\
\text { Hanley vie to control city c. 1890-1914. Machines } \\
\text { permanently defeated in 1914. Reform movement led } \\
\text { by president of National Cash Register. Rise of } \\
\text { Socialist party weakened machine working class } \\
\text { support. }\end{array}$ & Sealander 1988 \\
\hline
\end{tabular}


TABLE B-2-MACHINE CITIES

\begin{tabular}{|c|c|c|}
\hline City & Political History & Source \\
\hline Denver CO & $\begin{array}{l}\text { 1904-1918 run by the relatively Progressive Boss } \\
\text { Speer, who used patronage, support for infrastructure, } \\
\text { and efficient government to tie together a coalition of } \\
\text { urban poor and elites. One brief reform administration } \\
\text { in 1914. Speer dies in } 1918 \text {. }\end{array}$ & Dorsett 1976 \\
\hline Grand Rapids MI & $\begin{array}{l}\text { Boss Mayor Ellis controlled Grand Rapids from } 1906 \\
\text { until his death in 1916. Ellis built a coalition of } \\
\text { machine elements and reform policies, similar to } \\
\text { Mayor Speer in Denver. }\end{array}$ & Travis 1974 \\
\hline Hoboken NJ & $\begin{array}{l}\text { A classic machine with strong ties to the Irish } \\
\text { American community. }\end{array}$ & Foster and Clark 1976 \\
\hline Jersey City NJ & $\begin{array}{l}\text { During most of this period the political machine faced } \\
\text { strong opposition from reform politicians. Only after } \\
\text { structural election reform in } 1917 \text { did the ironclad } \\
\text { dominance of Boss Frank "I am the Law" Hague } \\
\text { emerge. }\end{array}$ & Foster 1968 \\
\hline Kansas City MO & $\begin{array}{l}\text { Boss Pendergast controlled Kansas City from before } \\
1900 \text { until his conviction in } 1939 .\end{array}$ & $\begin{array}{l}\text { Boulay and DiGaetano } \\
1985 \\
\text { Dorsett } 1968\end{array}$ \\
\hline Louisville KY & $\begin{array}{l}\text { Machine control in Louisville ended in } 1938 \text { with the } \\
\text { death of the last citywide boss, Mike Brennan. }\end{array}$ & $\begin{array}{l}\text { Boulay and DiGaetano } \\
1985\end{array}$ \\
\hline Lowell MA & $\begin{array}{l}\text { A classic machine with strong ties to the Irish } \\
\text { American community. }\end{array}$ & Blewett 1976 \\
\hline Memphis TN & $\begin{array}{l}\text { Boss Crump built support for a machine out of a } \\
\text { relatively unusual alliance of native born whites and } \\
\text { businessmen. }\end{array}$ & $\begin{array}{l}\text { Miller } 1957 \\
\text { DiGaetano } 1991\end{array}$ \\
\hline New Orleans LA & $\begin{array}{l}\text { State government supported machine. Boss } \\
\text { Behrman's machine combined spending on public } \\
\text { goods such as roads and education, and mass transit } \\
\text { with tolerance for gambling, prostitution, and illegal } \\
\text { alcohol sales. }\end{array}$ & $\begin{array}{l}\text { Buenker and Kantowicz } \\
1988\end{array}$ \\
\hline New York NY & $\begin{array}{l}\text { Tammany Hall, the most famous machine of all, ruled } \\
\text { New York under the direction of Boss Francis Murphy. }\end{array}$ & Weiss 1968 \\
\hline
\end{tabular}


TABLE B-2-MACHINE CITIES

\begin{tabular}{|c|c|c|}
\hline City & Political History & Source \\
\hline Omaha NE & $\begin{array}{l}\text { Boss Dennison controlled the city } 1900-\text { mid } 1920 \text { s. } \\
\text { The Dennison machine was one of the most openly } \\
\text { criminal machines in the nation. }\end{array}$ & Menard 1989 \\
\hline Peoria IL & $\begin{array}{l}\text { The machine of "Old Ed" Woodruff emerged before } \\
1910 \text { and dominated Peoria politics until } 1946 .\end{array}$ & $\begin{array}{l}\text { Boulay and DiGaetano } \\
1985\end{array}$ \\
\hline Philadelphia PA & $\begin{array}{l}\text { A Republican machine with ties to state boss Bois } \\
\text { Penrose. Close ties to business interests; cited by } \\
\text { Steffens as being especially good at ballot box } \\
\text { stuffing. }\end{array}$ & $\begin{array}{l}\text { Boulay and DiGaetano } \\
1985 \\
\text { Buenker and Kantowicz } \\
1988 \\
\text { Steffens [1904] } 1957\end{array}$ \\
\hline Pittsburgh PA & A Republican machine closely allied with business. & $\begin{array}{l}\text { Buenker and Kantowicz } \\
1988\end{array}$ \\
\hline Rochester NY & A Republican machine. & $\begin{array}{l}\text { Boulay and DiGaetano } \\
1985\end{array}$ \\
\hline St Louis MO & $\begin{array}{l}\text { Borderline machine. After defeat of Boss Butler in } \\
\text { 1902, State level Democratic party probably ran a } \\
\text { machine under Rolla Wells in 1900s. Machine politics } \\
\text { clearly re-emerges in 1910s and Boss Hannegan is } \\
\text { finally defeated in } 1941 .\end{array}$ & $\begin{array}{l}\text { Primm } 1981 \\
\text { Boulay and DiGaetano } \\
1985\end{array}$ \\
\hline Utica NY & $\begin{array}{l}\text { A Republican machine supported by Utica's large } \\
\text { Italian American community and a rival Irish political } \\
\text { establishment. }\end{array}$ & Bean 1994 \\
\hline
\end{tabular}

Notes: All references refer to sources listed in the References. 